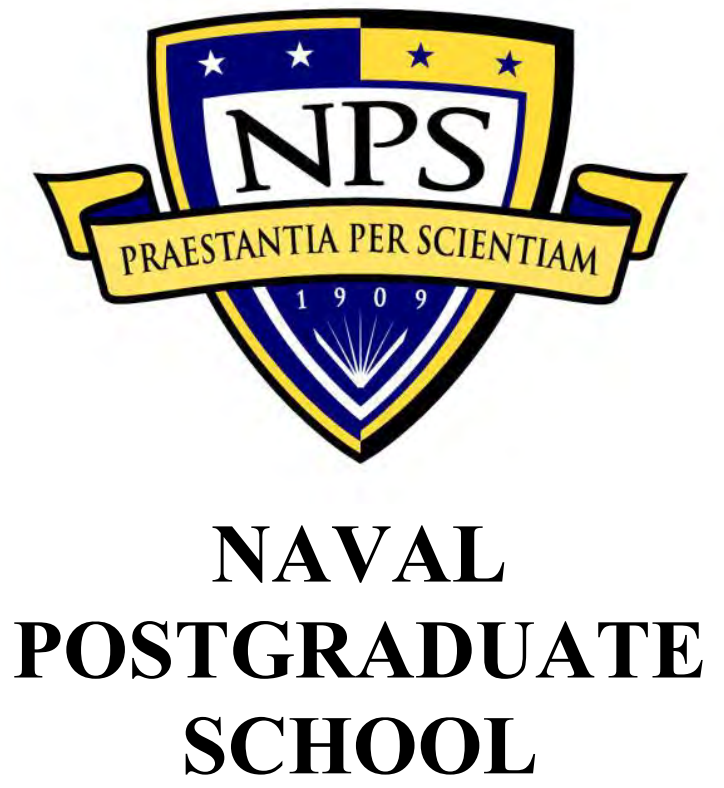

MONTEREY, CALIFORNIA

JOINT APPLIED PROJECT

\title{
LEVERAGING INTERNATIONAL COOPERATION ACQUISITION OPPORTUNITIES FOR THE DEPARTMENT OF DEFENSE
}

By: Frederick Evans, Jr.

Scott McConnell

September 2014

Advisors: $\quad$ Charles Pickar

Suzanne Arney 
THIS PAGE INTENTIONALLY LEFT BLANK 
Public reporting burden for this collection of information is estimated to average 1 hour per response, including the time for reviewing instruction, searching existing data sources, gathering and maintaining the data needed, and completing and reviewing the collection of information. Send comments regarding this burden estimate or any other aspect of this collection of information, including suggestions for reducing this burden, to Washington headquarters Services, Directorate for Information Operations and Reports, 1215 Jefferson Davis Highway, Suite 1204, Arlington, VA 22202-4302, and to the Office of Management and Budget, Paperwork Reduction Project (0704-0188) Washington DC 20503.

\section{AGENCY USE ONLY (Leave blank)}

4. TITLE AND SUBTITLE

LEVERAGING INTERNATIONAL COOPERATION ACQUISITION OPPORTUNITIES FOR THE DEPARTMENT OF DEFENSE

6. AUTHOR(S) Frederick Evans, Jr. and Scott McConnell

7. PERFORMING ORGANIZATION NAME(S) AND ADDRESS(ES)

Naval Postgraduate School

Monterey, CA 93943-5000

9. SPONSORING /MONITORING AGENCY NAME(S) AND ADDRESS(ES)

N/A

11. SUPPLEMENTARY NOTES The views expressed in this thesis are those of the author and do not reflect the official policy or position of the Department of Defense or the U.S. Government. IRB Protocol number

12a. DISTRIBUTION / AVAILABILITY STATEMENT

Approved for public release; distribution is unlimited Joint Applied Project
3. REPORT TYPE AND DATES COVERED

\section{PERFORMING ORGANIZATION REPORT NUMBER}

10. SPONSORING/MONITORING AGENCY REPORT NUMBER $\mathrm{N} / \mathrm{A}$

13. ABSTRACT (maximum 200 words)

Leveraging current and future International Cooperation opportunities, such as Foreign Military Sales and Cooperative Programs throughout the entire Department of Defense System Acquisition Framework could contribute to and enhance the systems acquired domestically and create additional Foreign Military Sales opportunities. Historically, International Cooperation is not considered in the acquisition process until sometime around initial operational capability or full operational capability. Considering International Cooperation earlier in the acquisition process may prove beneficial to the domestic side if Department of Defense systems can be developed and acquired to accommodate our foreign partner's interoperability requirements and releaseability restrictions.

The overall outcome of this study will be to identify the various entry points in the acquisition framework for International Cooperation and how that will benefit or deter the domestic program offices system acquisition efforts. Our research and analysis will focus on examples of various levels of effort that have been required to go back and retrofit a system to make it available to Foreign Military Sales and then identify where it could have been done more efficiently if considered earlier in the framework.

14. SUBJECT TERMS International Cooperation, Cooperative Programs/Development, Foreign Military Sales (FMS), Defense Acquisition, DOD Instruction 5000.01

\section{SECURITY}

CLASSIFICATION OF REPORT

Unclassified
18. SECURITY CLASSIFICATION OF THIS PAGE
19. SECURITY CLASSIFICATION OF ABSTRACT Unclassified
15. NUMBER OF PAGES

16. PRICE CODE

20. LIMITATION OF
ABSTRACT

UU

Standard Form 298 (Rev. 2-89)

Prescribed by ANSI Std. 239-18 
THIS PAGE INTENTIONALLY LEFT BLANK 
Approved for public release; distribution is unlimited

\title{
LEVERAGING INTERNATIONAL COOPERATION ACQUISITION OPPORTUNITIES FOR THE DEPARTMENT OF DEFENSE
}

\author{
Frederick Evans Jr., Civilian, Department of the Navy \\ Scott McConnell, Civilian, Department of the Navy \\ Submitted in partial fulfillment of the requirements for the degree of \\ MASTER OF SCIENCE IN PROGRAM MANAGEMENT \\ from the \\ NAVAL POSTGRADUATE SCHOOL \\ September 2014
}

Authors: $\quad$ Frederick Evans Jr.

Scott McConnell

Approved by: $\quad$ Charles Pickar

Suzanne Arney

William R. Gates, Dean

Graduate School of Business and Public Policy 
THIS PAGE INTENTIONALLY LEFT BLANK 


\title{
LEVERAGING INTERNATIONAL COOPERATION ACQUISITION OPPORTUNITIES FOR THE DEPARTMENT OF DEFENSE
}

\begin{abstract}
Leveraging current and future International Cooperation opportunities, such as Foreign Military Sales and Cooperative Programs throughout the entire Department of Defense System Acquisition Framework could contribute to and enhance the systems acquired domestically and create additional Foreign Military Sales opportunities. Historically, International Cooperation is not considered in the acquisition process until sometime around initial operational capability or full operational capability. Considering International Cooperation earlier in the acquisition process may prove beneficial to the domestic side if Department of Defense systems can be developed and acquired to accommodate our foreign partner's interoperability requirements and releaseability restrictions.

The overall outcome of this study will be to identify the various entry points in the acquisition framework for International Cooperation and how that will benefit or deter the domestic program offices system acquisition efforts. Our research and analysis will focus on examples of various levels of effort that have been required to go back and retrofit a system to make it available to Foreign Military Sales and then identify where it could have been done more efficiently if considered earlier in the framework.
\end{abstract}


THIS PAGE INTENTIONALLY LEFT BLANK 


\section{TABLE OF CONTENTS}

I. INTRODUCTION. 1

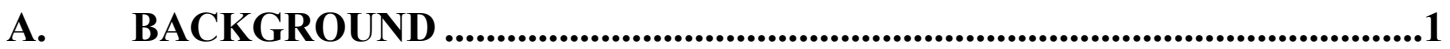

B. PROBLEM IDENTIFICATION AND ANALYSIS PLANNING .................3

C. PROJECT OBJECTIVES...............................................................4

D. REPORT ORGANIZATION.........................................................................5

E. EXPECTED ACCOMPLISHMENTS ...........................................................5

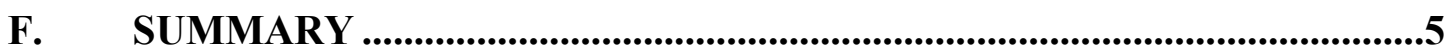

II. DEFENSE ACQUISITION WITH INTERNATIONAL INVOLVEMENT .........7

A. OVERVIEW ...................................................................................................7

B. DRILLING DOWN, PROGRAMS DEFINED ................................................7

1. Security Assistance..........................................................................8

2. Security Cooperation .......................................................................8

C. DEFENSE ACQUISITION INTERNATIONAL PROGRAMS ..................9

D. INTERNATIONAL ARMAMENTS COOPERATION PROJECTS........10

1. International Forums..............................................................................10

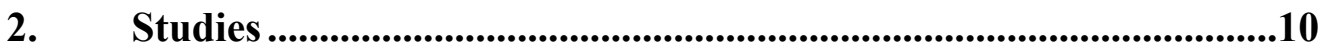

3. RDT\&E Information Exchange Program .........................................10

4. Engineers and Scientists Exchange Program .......................................11

5. Test and Evaluation Program.................................................................11

6. Foreign Comparative Testing .................................................................11

7. Cooperative Research, Development, and Production.......................11

8. No Cost Equipment Loans for RDT\&E...............................................12

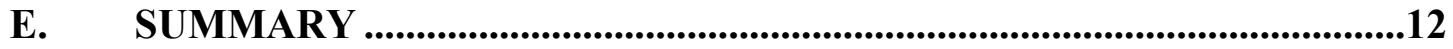

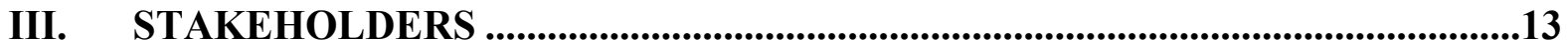

A. INTRODUCTION TO FMS/CP STAKEHOLDERS....................................13

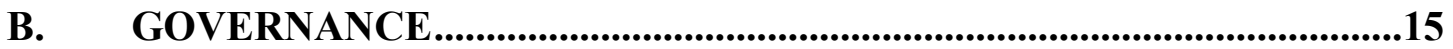

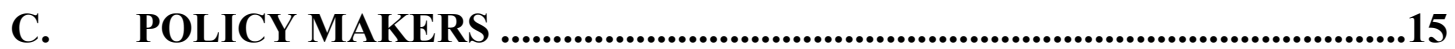

D. USG CUSTOMERS ........................................................................................15

E. EMBASSY TEAMS ...................................................................................16

F. FOREIGN CUSTOMER...............................................................................16

G. SYSTEMS COMMANDS …..........................................................17

H. PROGRAM OFFICES .....................................................................17

I. EXECUTING ACTIVITIES............................................................................17

J. OTHER COMMANDS...................................................................................18

K. STAKEHOLDER SUMMARY ............................................................18

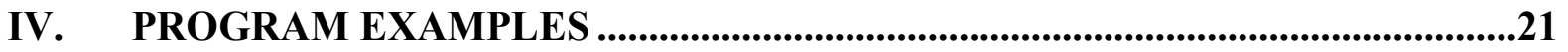

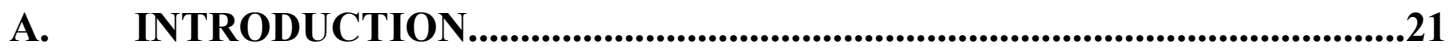

B. GLOBAL COMMAND \& CONTROL SYSTEM-JOINT ..........................21

1. Program Description .................................................................................21

2. System Description.........................................................................21

3. GCCS-J International Involvement ......................................................22 
4. SWOT.

C. GLOBAL COMMAND \& CONTROL SYSTEM-MARITIME

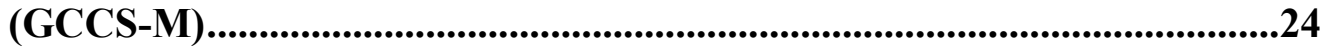

1. Program Description .......................................................................24

2. GCCS-M International Involvement .........................................24

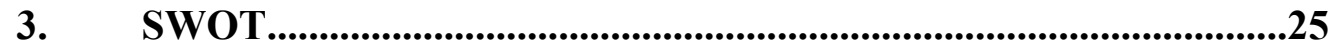

D. FIGHTER/ATTACK (F/A)-18 ...............................................................26

1. Program Description ..............................................................................26

2. F/A-18 International Involvement...................................................227

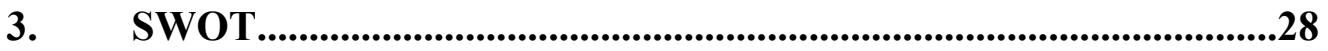

E. AIR TRAFFIC NAVIGATION, INTEGRATION, AND COORDINATION SYSTEM (ATNAVICS) ...........................................29

1. System Description......................................................................29

2. Program Description .........................................................................29

3. International Involvement....................................................................30

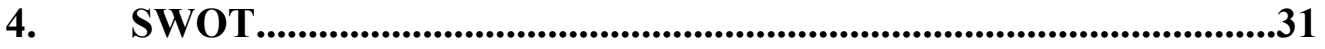

F. APACHE ATTACK HELICOPTER (AH-64) ......................................32

1. System Description....................................................................32

2. Program Description ..................................................................33

3. International Involvement.....................................................................33

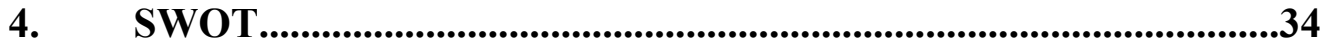

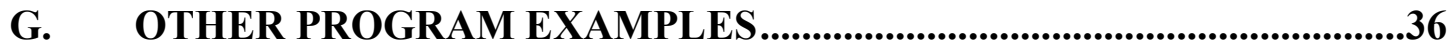

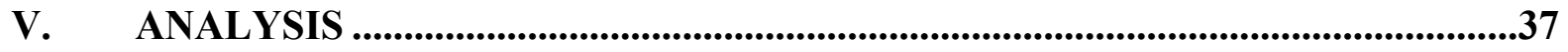

A. ANALYSIS OF PROGRAM RESEARCH ....................................................37

1. SWOT Comparison ....................................................................................37

a. Cost SWOT Comparison........................................................37

b. Schedule SWOT Comparison .................................................38

c. Performance SWOT Comparison..........................................38

2. SWOT Analysis .....................................................................39

3. Process for FMS/CP Engagement ......................................................45

4. Entry Points in Defense Acquisition Cycle .........................................46

a. Early Acquisition...............................................................46

b. Middle Acquisition .............................................................47

c. Late Acquisition .............................................................49

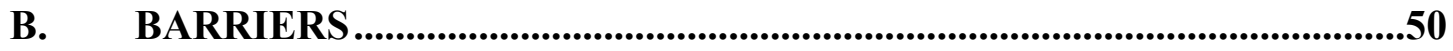

1. Security ................................................................................5.51

2. Expectation Challenges ...........................................................52

3. Implied/actual Added Cost in Future International Engagements.....................................................................................52

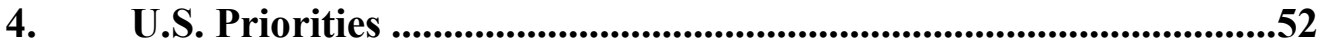

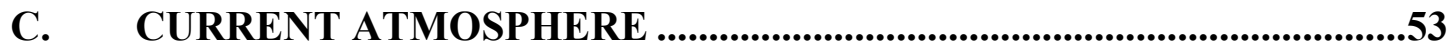

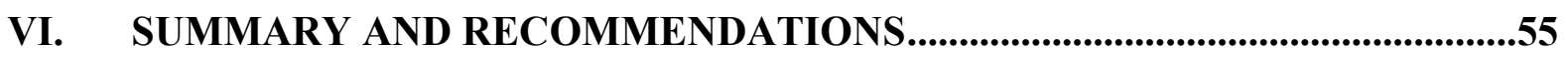

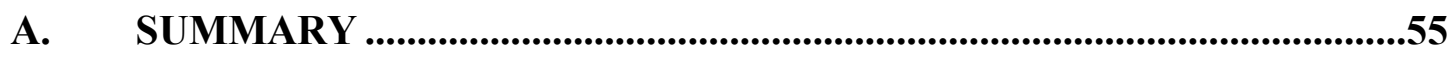

B. RECOMMENDATIONS....................................................................56 

1. Increase the DOD International Program and Foreign Military Sales Staffing ..........................................................................................56
2. In-depth Analysis of the Joint Strike Fighter Program ..................56
C. CONCLUSION ..................................................................................57

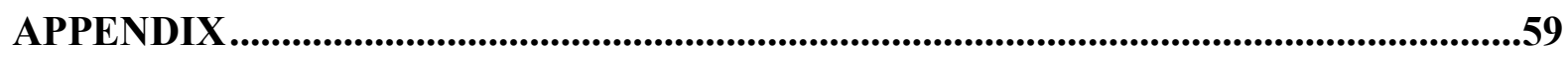

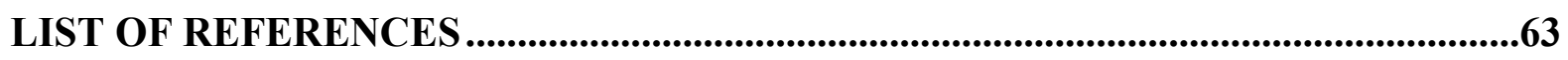

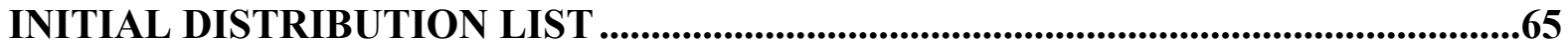


THIS PAGE INTENTIONALLY LEFT BLANK 


\section{LIST OF FIGURES}

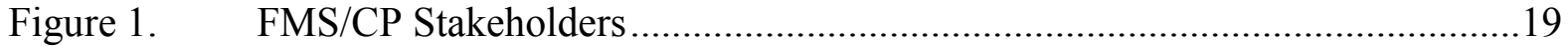

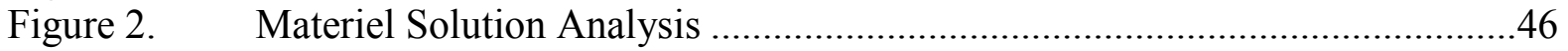

Figure 3. Technology Maturation and Risk Reduction ................................................47

Figure 4. $\quad$ Engineering \& Manufacturing Development.............................................48

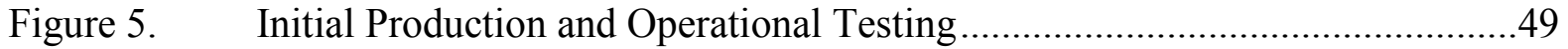

Figure 6. $\quad$ Production, Operations \& Support...............................................................50 
THIS PAGE INTENTIONALLY LEFT BLANK 


\section{LIST OF TABLES}

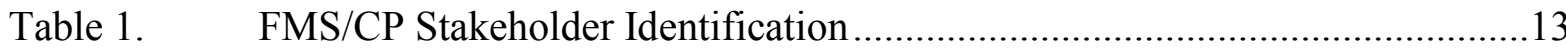

Table 2. $\quad$ SWOT Comparison for Cost, Schedule and Performance.............................40

Table 3. Security Assistance Programs.....................................................................59

Table 4. $\quad$ Security Cooperation Programs ...............................................................61 
THIS PAGE INTENTIONALLY LEFT BLANK 


\section{LIST OF ACRONYMS AND ABBREVIATIONS}

ACAT

AEHF

AFRICOM

$\mathrm{AH}$

ASN

$\mathrm{ASN}(\mathrm{RD} \& \mathrm{~A})$

ASR

AT\&L

ATNAVICS

ATS

BBP

$\mathrm{C} 2$

C4I

CCA

CCDR

CECOM

CENTCOM

CINC

COCOM

$\mathrm{CP}$

CPI

DAB

DAG

DAS

DAU

DCS

DISA

DOD

DOS acquisition category

advanced extremely high frequency

Africa Command

attach helicopter

Assistant Secretary of the Navy

Assistant Secretary of the Navy for Research Development and Acquisition

airport surveillance radar

Acquisition, Technology and Logistics

Air Traffic Navigation, Integration, and Coordination System

air traffic services

Better Buying Power

command and control

command, control, communications, computers and intelligence

close combat attack

combatant commander

communications-electronic command

central command

Commander-in-Chief

combatant command

cooperative program

critical protection information

Defense Acquisition Board

Defense Acquisition Guidebook

defense acquisition system

Defense Acquisition University

direct commercial sales

Defense Information System Agency

Department of Defense

Department of State 


$\begin{array}{ll}\text { DSCA } & \text { Defense Security Cooperation Agency } \\ \text { DT } & \text { developmental testing } \\ \text { EAC } & \text { echelons above corps } \\ \text { EMD } & \text { engineering and manufacturing development } \\ \text { EOL } & \text { end of life } \\ \text { EUCOM } & \text { Europe Command } \\ \text { F/A } & \text { fighter/attack } \\ \text { FCT } & \text { foreign comparative testing } \\ \text { FFRDC } & \text { Federally Funded Research and Development Centers } \\ \text { FMS } & \text { foreign military sales } \\ \text { FOC } & \text { full operational capability } \\ \text { FRP } & \text { full rate production } \\ \text { FY } & \text { fiscal year } \\ \text { GCCS-J } & \text { Global Command and Control System-Joint } \\ \text { GCCS-M } & \text { Global Command and Control System-Maritime } \\ \text { HMMWV } & \text { high mobility multipurpose wheeled vehicle } \\ \text { IA } & \text { information assurance } \\ \text { IAC } & \text { international armaments cooperation } \\ \text { IFF } & \text { identify friend or foe } \\ \text { IOC } & \text { initial operational capability } \\ \text { IOT\&E } & \text { initial operational testing \& evaluation } \\ \text { IP } & \text { international programs } \\ \text { IPO } & \text { International Program Office } \\ \text { IPT } & \text { integrated process/product team } \\ \text { IT } & \text { information technology } \\ \text { JCIDS } & \text { Joint Capabilities Integration Development System } \\ \text { JSF } & \text { Joint Strike Fighter } \\ \text { MAIS } & \text { Major Automated Information System } \\ \text { MIDS } & \text { Multifunctional Information Distribution System } \\ \text { MUOS } & \text { Mobile User Objective System } \\ \text { NATO } & \text { North American Treaty Organization } \\ \text { NAVSUP } & \text { Naval Supply Systems Command } \\ & \\ & \end{array}$




$\begin{array}{ll}\text { NDI } & \text { non-developmental item } \\ \text { NETSAFA } & \text { Naval Education and Training Security Assistance Field Activity } \\ \text { NIPO } & \text { Navy International Program Office } \\ \text { NMCC } & \text { National Military Command Center } \\ \text { NORTHCOM } & \text { Northern Command } \\ \text { NSA } & \text { National Security Agency } \\ \text { ORD } & \text { operational requirements document } \\ \text { OT } & \text { operational test } \\ \text { PACOM } & \text { Pacific Command } \\ \text { PAR } & \text { precision approach radar } \\ \text { PEO } & \text { program executive office(r) } \\ \text { PM } & \text { program manager } \\ \text { PMA } & \text { program manager air } \\ \text { PMS } & \text { program manager ships } \\ \text { PMW } & \text { program manager warfare } \\ \text { PO } & \text { program office } \\ \text { POR } & \text { program of record } \\ \text { PPBE } & \text { Planning, Programming, Budgeting and Execution } \\ \text { RDT\&E } & \text { research, development, testing and evaluation } \\ \text { SA } & \text { security assistance } \\ \text { SC } & \text { security cooperation } \\ \text { SecDef } & \text { Secretary of Defense } \\ \text { SOUTHCOM } & \text { Southern Command } \\ \text { SSCO } & \text { SYSCOM security cooperation office } \\ \text { SSR } & \text { secondary surveillance radar } \\ \text { SWOT } & \text { strengths, weaknesses, opportunities and threats } \\ \text { SYSCOM } & \text { system command } \\ \text { T\&E } & \text { test \& evaluation } \\ \text { TEP } & \text { test and evaluation plan } \\ \text { TRM } & \text { transmit/receive modules } \\ \text { TTO } & \\ \text { UCC } & \\ & \text { Technology Transfer Office } \\ & \end{array}$




$\begin{array}{ll}\text { U.S. } & \text { United States } \\ \text { USA } & \text { United States Army } \\ \text { USAF } & \text { United States Air Force } \\ \text { USASAC } & \text { United States Army Security Assistance Command } \\ \text { USASAC } & \text { United States Army Security Assistance Command } \\ \text { USC } & \text { United States Code } \\ \text { USG } & \text { United States government } \\ \text { USN } & \text { United States Navy } \\ \text { WCF } & \text { working capital funds } \\ \text { WSS } & \text { weapon systems support }\end{array}$




\section{ACKNOWLEDGMENTS}

The authors would like to thank their advisors, Dr. Charles Pickar and Ms. Suzanne Arney, for their guidance and expertise in completing this Joint Applied Project. The authors would also like to thank Mr. Erwin L. Hunter from the Army Air Traffic Control Product Office and Mr. David P. Miller of the Army Attack Helicopter Product Office. Mr. Hunter and Mr. Miller provided helpful information and insight related to the ATNAVICS system and the AH-64 Apache system and the international efforts in place with those product offices. Finally, the authors are immensely grateful for the support and understanding from their families throughout the achievement of their academic and professional goals. 
THIS PAGE INTENTIONALLY LEFT BLANK 


\section{INTRODUCTION}

This chapter will describe the research and make the case for why leveraging international cooperation opportunities can potentially benefit Department of Defense (DOD) programs. The goal of the paper is to provide existing and future domestic Program Managers with information and processes that could help them fully consider international cooperation and the potential benefits to their domestic program as it relates to cost, schedule and performance. The paper will examine several United States Army (USA) and United States Navy (USN) programs and the cost/benefit of leveraging security cooperation opportunities, such as foreign military sales (FMS), and International Cooperative Programs (ICP) to contribute to and enhance the domestic systems they develop and/or acquire. The paper will only contain public release information and will be based primarily on a comparative analysis of domestic programs who have considered international cooperation early, middle, and late or not at all in their acquisition life cycles. An explanation will be provided regarding the scope of the research and how the research will be conducted. The thesis organization will also be explained to include background, problem identification, objectives, organization and expected accomplishments.

\section{A. BACKGROUND}

Leveraging current and future international cooperation opportunities, such as FMS and CP throughout the entire DOD System Acquisition Framework could contribute to and enhance the systems acquired domestically and create additional international cooperation opportunities. Title 10 USC. 2350a(e) and amended by Section 1251 of the National Defense Authorization Act for Fiscal Year 2008 requires an analysis of potential opportunities for international cooperation for all acquisition category (ACAT) I programs before the first milestone or decision point. ${ }^{1}$ Non-ACAT 1 programs however, are sometimes not considered for international cooperation in the acquisition process

${ }^{1}$ Under Secretary of Defense (AT\&L), The Defense Acquisition System, DOD Directive 5000.1 (Washington, DC: Under Secretary of Defense (AT\&L), 2007). 
until sometime around initial operational capability (IOC) or full operational capability (FOC). The objectives of international cooperation in Acquisition, Technology and Logistics (AT\&L) emphasize operational, economic, technical, political, and industrial benefits to all stakeholders. Considering international cooperation earlier in the acquisition process may prove beneficial to the domestic side if DOD systems can be developed and acquired to accommodate our foreign partner's interoperability requirements and releaseability restrictions. At any ACAT level, the key is applying the appropriate amount of international cooperation consideration as early as possible and not just checking the box on international cooperation consideration.

As part of international cooperation, FMS provides the processes to conduct sales and transfers of services and equipment to foreign allies in support of interoperability. For FMS, Acquisition Managers take what has been developed for domestic use and tailor it for FMS or in some cases include FMS considerations within the development. Similarly, international cooperation is used to "reduce weapons system acquisition costs through cooperative development, production and support, foreign military sales and direct commercial sales in accordance with defense guidance."2

As stated by the Defense Security Cooperation Agency, "Security Cooperation (SC) comprises all activities undertaken by the DOD and security establishments, including all DOD-administered Security Assistance (SA) programs, that build defense and security relationships; promote specific U.S. security interests, including all international armaments cooperation activities and SA activities; develop allied and friendly military capabilities for self-defense and multinational operations; and provide U.S. forces with peacetime and contingency access to host nations." 3 U.S. Combatant Commands (COCOM) worldwide rely heavily on the defense capabilities of our allies to participate and interoperate effectively.

\footnotetext{
2 "International Cooperation in DOD Acquisition," last modified September 5, 2014, http://acq.osd.mil/ic/Intl\%20Coop\%20in\%DOD\%20ACQ.html.

3 Defense Security Cooperation Agency, Electronic-Security Assistance Management Manual, DODD 5105.38M (Arlington VA: Defense Security Cooperation Agency, 2012).
} 
FMS/CP are conduits to interoperability with our foreign allies. As DOD systems become fielded and deemed releasable, they are sold or transferred to certain foreign allies to facilitate the goals of international cooperation. Significant modifications as a result of releaseability, site/platform integration and affordability are often necessary to accommodate unique foreign requirements and/or export controls. Planning upfront for acquisitions in partnership with our foreign allies could benefit the DOD in numerous ways such as cooperative development, cost sharing, economies of scale and quicker implementation times for our allies.

\section{B. PROBLEM IDENTIFICATION AND ANALYSIS PLANNING}

The overall problem to be researched and analyzed is that a lack of consideration of foreign partner use or cooperative development by program offices (PO) that are developing and/or acquiring domestic military capabilities could result in missed opportunities for the PO. The informed foundation for this thesis will be primarily from DOD Instruction 5000.01 and use of USN and USA program of record (POR) program office research, combatant commander requirements and FMS/CP research. The Security Assistance Management Manual and the Defense Acquisition Guidebook (DAG) will also be utilized as references. The analysis will utilize methods such as comparative and cost/benefit. Specific research questions, including required analysis to help solve this problem are identified as follows:

\section{Question 1}

- Can early and continuous consideration of foreign interoperability requirements within domestic DOD acquisitions benefit the United States Armed Forces acquisitions in terms of cost, schedule and performance?

- Analysis Needed: Comparative and cost/benefit and risk analysis and SWOT

- $\quad$ Research Needed: Examples of U.S. DOD domestic projects and programs that have included, retrofitted or excluded foreign interoperability requirements. 


\section{Question 2}

- How does a domestic Program Office determine if foreign interoperability requirements exist for their product(s) and/or service(s)?

- $\quad$ Analysis Needed: Determine FMS/CP processes as well as stakeholder considerations and expectations

- $\quad$ Research Needed: Current U.S. National Security and Foreign Policy, COCOM missions/objectives; Specific foreign requests, alternative capability solutions

\section{Question 3}

- How does a domestic Program Office implement foreign interoperability requirements into their product(s) and/or service(s)?

- Analysis Needed: Based on FMS/CP processes and stakeholder consideration determine what existing FMS/CP accommodations are in the DOD Acquisition framework. Also determine any gaps, detriments or barriers.

- $\quad$ Research Needed: Specific references from DOD Instruction 5000.01 and the Security Assistance Management Manual

\section{PROJECT OBJECTIVES}

The objectives of this project will be as follows:

- $\quad$ Identify the various entry and exit points in the acquisition framework for FMS/CP with an assessment of the opportunities \& risks associated with earlier inclusion of the FMS/CP effort.

- Identify risk/reward and opportunity/barriers to the domestic program offices system acquisition that could prevent international involvement or use.

- $\quad$ Propose a process and/or entry points to assist domestic Project Managers in determining if FMS/CP can be leveraged to benefit their programs.

- $\quad$ Provide an analysis of all FMS/CP stakeholders' perspective in order to facilitate a comprehensive understanding of expectations through the process.

- $\quad$ Conduct research and analysis with a focus on examples of various levels of effort that have been required to re-engineer and/or retrofit a system to make it available to FMS/CP.

- Identify efficiency opportunities if FMS/CP is considered earlier in the framework. 


\section{REPORT ORGANIZATION}

Chapter I of this research report outlines why this subject is important and presents the scope of the research conducted, initial background, problem identification, objectives and expected accomplishments. Chapter II will provide a comprehensive background on international cooperation including existing touch points within the DOD Acquisition framework. Chapter III will detail all stakeholder considerations and expectations. Chapter IV will provide specific examples and findings of programs/projects where early inclusion was considered and examples where retrofits and/or non-modifiable decisions were made. Chapter V will present conclusions and recommendations for potential process improvements and/or further research.

\section{E. EXPECTED ACCOMPLISHMENTS}

This project will provide an overview of international cooperation to include types of FMS and cooperative programs. Existing processes for program office consideration of foreign interoperability requirements will be explained and explored.

- $\quad$ Process for international cooperation in AT\&L and FMS consideration by program manager (PM)

- Define stakeholder considerations and expectations

- $\quad$ Specific examples of early inclusion

- $\quad$ Specific examples of late inclusion resulting in FMS retrofit

\section{F. SUMMARY}

This chapter has set the foundation for exploring the utilization of U.S. interoperability requirements of our foreign allies in order to enhance, expand and potentially reduce the cost of our domestically acquired capabilities. This utilization may not only reduce the domestic acquisition burden through areas such as economies of scale and price reductions; it could also better equip our allies and render them more effective coalition partners and potentially assist with and international relations. We examine international cooperation and its placement in the overall Security Cooperation supporting U.S. National Security objectives in the next chapter. 
THIS PAGE INTENTIONALLY LEFT BLANK 


\section{DEFENSE ACQUISITION WITH INTERNATIONAL INVOLVEMENT}

\section{A. OVERVIEW}

International Involvement as it relates to Defense Acquisition can be conducted through three types of programs; international armaments cooperation (IAC), foreign military sales (FMS), and direct commercial sales (DCS). Decisions made on every acquisition program throughout the entire acquisition life cycle can determine which, if any, of the programs is appropriate, or even possible. Defense Acquisition is a very complex business. While there are many factors that contribute to complexity, international involvement includes additional stakeholder consideration as well as the added technical complexity to meet international requirements for operation and releaseability. To most Program Managers, increased complexity translates to increased risk and uncertainty. The tendency is usually to reduce risk, eliminate uncertainty, increase direct control and as a result, improve the potential for program success. Following this tendency may result in missed opportunities for realizing the potential benefits that international involvement can bring to our National Defense. Program Management Teams, to be effective in this area, need a great deal of knowledge and assistance in order to navigate the complex intertwining of Defense Acquisition and International involvement. This chapter provides an overview of the International programs and lays a foundation for understanding the multiple opportunities that exist when considering them from a Defense Acquisition perspective.

\section{B. DRILLING DOWN, PROGRAMS DEFINED}

To better understand the three basic programs mentioned above; FMS, DCS and IAC, we will start at the top level and then drill down. At the National level, there are two categories of international programs, security assistance (SA) and security cooperation (SC). 


\section{Security Assistance}

As per the Security Assistance Management Manual (SAMM) the following definition of Security Assistance is provided:

SA is a group of programs, authorized under Title 22 authorities, by which the United States provides defense articles, military education and training, and other defense-related services by grant, loan, credit, cash sales, or lease, in furtherance of national policies and objectives. All SA programs are subject to the continuous supervision and general direction of the Secretary of State to best serve U.S. foreign policy interests; however, programs are variously administered by DOD or Department of State (DOS). Those SA programs that are administered by DOD become a subset of SC. ${ }^{4}$

\section{Security Cooperation}

As per the SAMM the following definition of Security Cooperation is provided:

SC comprises all activities undertaken by the Department of Defense (DOD) to encourage and enable international partners to work with the United States to achieve strategic objectives. It includes all DOD interactions with foreign defense and security establishments, including all DOD-administered Security Assistance (SA) programs, that build defense and security relationships; promote specific U.S. security interests, including all international armaments cooperation activities and SA activities; develop allied and friendly military capabilities for self-defense and multinational operations; and provide U.S. forces with peacetime and contingency access to host nations. It is DOD policy that $\mathrm{SC}$ is an important tool of national security and foreign policy and is an integral element of the DOD mission. SC activities shall be planned, programmed, budgeted, and executed with the same high degree of attention and efficiency as other integral DOD activities. SC requirements shall be combined with other DOD requirements and implemented through standard DOD systems, facilities, and procedures. See DODD 5132.03.5

The key differences between SA and SC are in the authorization, appropriation, and governing legal statutes for each. SA is authorized under Title 22 and SC is under

\footnotetext{
${ }^{4}$ Defense Security Cooperation Agency, Electronic-Security Assistance Management Manual, DODD 5105.38M (Arlington VA: Defense Security Cooperation Agency, 2012).

5 Defense Security Cooperation Agency, Electronic-Security Assistance Management Manual, DODD 5105.38M (Arlington VA: Defense Security Cooperation Agency, 2012).
} 
Title 10, being authorized under the National Defense Authorization and Appropriation Acts. All Security Assistance Programs executed by the DOD become Security Cooperation Programs. See Table 3 in the Appendix for a full listing of SP programs and Table 4 in the Appendix for a full listing of SC programs with brief descriptions of all.

\section{DEFENSE ACQUISITION INTERNATIONAL PROGRAMS}

Drilling down another level by filtering out the programs in tables 3 and 4 that are not associated with military equipment and/or material development, the three previously mentioned programs remain valid considerations for Acquisition Program Managers; FMS, DCS and IAC. All three of these programs seek to enhance U.S. national security, but do so through different methods. While FMS and DCS programs predominately involve the sale of various defense systems that the DOD has already developed and deployed to its own forces, IAC predominantly focuses on interfacing with international

partners during the research, development, testing and evaluation (RDT\&E) and production phases of the U.S. systems acquisition process.

\section{Foreign Military Sales}

Commonly known as simply FMS, is the purchase of U.S. Defense articles, services and training by eligible foreign governments from the U.S. government.

\section{Direct Commercial Sales}

Referred to as DCS is the purchase of U.S. Defense articles by eligible Foreign Governments from the U.S. Manufacturing Contractor, with an approved export license issued by DOS and approved by Congress.

\section{International Armaments Cooperation}

Also known as International Cooperation in the Defense Acquisition Guidebook (DAG) is defined as:

Any acquisition program or technology project that includes participation by one or more foreign nations, through an international agreement, during any phase of a system's life cycle. The key objectives of international cooperative programs are to reduce weapons system acquisition costs 
through cooperative development, production, and support; and to enhance interoperability with coalition partners. ${ }^{6}$

\section{INTERNATIONAL ARMAMENTS COOPERATION PROJECTS}

IAC has several sub-efforts, or projects that span the entire defense acquisition system (DAS) as described below.

\section{International Forums}

To support early understanding of mutual needs, capabilities and technology with potential International Cooperating Partner Nations, engineers, researchers and managers should participate in the appropriate International Forums. There are several, including North Atlantic Treaty Organization's (NATO) Science and Technology Organization and over thirty bilateral forums with countries across the globe. Continued participation in forums, throughout a systems development life cycle can facilitate the sharing of knowledge, best practices and lessons learned, while also contributing to the harmonization of standards and requirements.

\section{Studies}

Early acquisition efforts that have potential International interest would benefit from the conduct of studies to assess critical areas. These areas include feasibility, availability, technology maturity, potential requirements/capability gaps and support the Analysis of Alternatives prior to a system entering Milestone A. Studies can be conducted by industry, government or a combination of both.

\section{RDT\&E Information Exchange Program}

This is the exchange of technical data with other countries to further the RDT\&E effort of a U.S. weapons system. This program has the potential to reduce the time and cost of developing a system. There generally must be an actual, or established, U.S. requirement that the exchange of data supports.

\footnotetext{
6 Defense Acquisition University, Defense Acquisition Guidebook (DAG), online version, https://dag.dau.mil/Pages/Default.aspx, September 2014.
} 


\section{Engineers and Scientists Exchange Program}

The mutual exchange of military or civilian engineers and scientists, typically in a permanent change of station arrangement, for the purpose of becoming producing members of the host nation military RDT\&E community can benefit both countries involved in the exchange. This facilitates a better understanding of the other nation's technologies and capabilities while allowing an engineer or scientist to contribute as a member of the assigned nations RDT\&E community and potentially provide career enhancement within the parent organization.

\section{Test and Evaluation Program}

Test and Evaluation Program (TEP) agreements establish cooperative and reciprocal test and evaluation activities. This includes cooperative testing, evaluation and can also include Reciprocal Use of Test Facilities (RUTF) agreements. Interoperability assessment can be enhanced with earlier, less costly identification of problems and more affordable testing of solutions. Sharing of resources and data can increase mission capability for the U.S. and our allies.

\section{Foreign Comparative Testing}

In a Foreign Comparative Testing (FCT) effort, the U.S. can test and evaluate foreign weapons systems or components to identify the potential to fill a U.S. military requirement or overcome an operational gap with a reduction in cost and schedule of a potential system fielding. FCT also facilitates interoperability and standardization with our allies.

\section{Cooperative Research, Development, and Production}

Spanning a very large spectrum of the DAS, these bilateral or multilateral agreements are for the cost-sharing of research, development and production of a system. The most prominent example of this in the 21st century is the F-35 Joint Strike Fighter which has foreign cooperative partners including the United Kingdom, Canada, Australia and several others. Opportunities can also exist for a much smaller and far less 
intimidating cooperative effort which may only span the development and/or production of a system, or product improvement, as compared to the entire system life cycle.

\section{No Cost Equipment Loans for RDT\&E}

In this effort, the U.S. can loan defense equipment to other countries to support their RDT\&E programs but with the requirement that the test results are provided back to the U.S... An interesting caveat here is that loaned equipment could be expended, for example, during live fire testing or other destructive tests, without reimbursement.

\section{E. SUMMARY}

FMS and DCS are the most widely recognized foreign partner acquisition methods, but real benefit can be gained from using the full spectrum of international programs including IAC with the appropriate projects identified above. Proper consideration should be given at every decision point along the DAS for the appropriate level of international involvement based on a fully informed cost/benefit analysis. Additional Stakeholders always bring potential for added schedule risk, pressure for requirements creep, and the likely scenario of simultaneous cost increase and cost risk. The potential upside though is leveraging international efforts for a stronger, more effective war fighting coalition that can seamlessly operate and communicate. 


\section{STAKEHOLDERS}

\section{A. INTRODUCTION TO FMS/CP STAKEHOLDERS}

Stakeholders are individuals and groups who influence, are impacted by or have an interest in FMS/CP. This chapter will provide a description of FMS/CP stakeholders and their organizations in order to facilitate a comprehensive understanding of their expectations through the acquisition process. For each stakeholder identified, a description of their role will be provided. In addition, each stakeholder's perspective will be examined in order to understand their expectations throughout the acquisition process. Finally, an interface diagram will be presented to show the relationships and dependencies amongst all the stakeholders. For the purposes of this research paper, the stakeholders covered are U.S. Navy- and U.S. Army-centric and will fall in nine (9) focus areas, as identified in Table 1.

Table 1. FMS/CP Stakeholder Identification

\begin{tabular}{|l|l|l|}
\hline $\begin{array}{l}\text { Stakeholder } \\
\text { Group }\end{array}$ & Description & Stakeholder Organization \\
\hline Governance & $\begin{array}{l}\text { "Chain of Command" } \\
\text { Policy/Strategy } \\
\text { Decision authority for } \\
\text { Program Offices } \\
\text { Export }\end{array}$ & $\begin{array}{l}\text { Congress } \\
\text { Department of Defense } \\
\text { Department of State } \\
\text { Assistant Secretary of the Navy (ASN) } \\
\text { Research, Development \& Acquisition (RDA) } \\
\text { Deputy ASN International Programs } \\
\text { (IP)/Navy international program office(NIPO) } \\
\text { United States Army Security Assistance } \\
\text { Command (USASAC) } \\
\text { Program executive offices (PEO) }\end{array}$ \\
\hline $\begin{array}{l}\text { Policy } \\
\text { Makers }\end{array}$ & $\begin{array}{l}\text { Establish policies } \\
\text { impacting security } \\
\text { assistance, including } \\
\text { foreign military sales } \\
\text { Authority for what } \\
\text { products/ capabilities can } \\
\text { be exported }\end{array}$ & $\begin{array}{l}\text { (DSCA) } \\
\text { Navy International Program Office (NIPO) } \\
\text { United States Army Security Assistance } \\
\text { Command (USASAC) } \\
\text { National Security Agency (NSA) }\end{array}$ \\
\hline $\begin{array}{l}\text { U.S. } \\
\text { Government } \\
\text { Customers }\end{array}$ & $\begin{array}{l}\text { Conduct military } \\
\text { operations in their area of } \\
\text { responsibility } \\
\text { Based on military strategies }\end{array}$ & $\begin{array}{l}\text { Unified Combatant Commands } \\
\text { (UCC)/(COCOMS) } \\
\text { AFRICOM (Africa) } \\
\text { CENTCOM (Central) }\end{array}$ \\
\hline
\end{tabular}




\begin{tabular}{|c|c|c|}
\hline $\begin{array}{l}\text { Stakeholder } \\
\text { Group }\end{array}$ & Description & Stakeholder Organization \\
\hline & $\begin{array}{l}\text { and cooperation plans, } \\
\text { establishes requirements } \\
\text { for foreign nation } \\
\text { capabilities } \\
\text { Equips and trains non- } \\
\text { traditional foreign partners }\end{array}$ & $\begin{array}{l}\text { EUCOM (Europe) } \\
\text { NORTHCOM } \\
\text { PACOM (Pacific) } \\
\text { SOUTHCOM } \\
\text { Naval Component Commands and Fleet } \\
\text { Commanders }\end{array}$ \\
\hline $\begin{array}{l}\text { Foreign } \\
\text { Customers }\end{array}$ & $\begin{array}{l}\text { Non-U.S. nations that } \\
\text { procure and use U.S. } \\
\text { military products and } \\
\text { systems or receive training } \\
\text { and other support }\end{array}$ & $\begin{array}{l}\text { Coalition partners and other foreign } \\
\text { governments }\end{array}$ \\
\hline $\begin{array}{l}\text { Embassy } \\
\text { Teams }\end{array}$ & $\begin{array}{l}\text { In-Country Team based at } \\
\text { U.S. embassies }\end{array}$ & $\begin{array}{l}\text { Security Cooperation Organizations, to } \\
\text { include Department of State and DOD } \\
\text { personnel at U.S. embassies }\end{array}$ \\
\hline $\begin{array}{l}\text { System } \\
\text { Commands }\end{array}$ & $\begin{array}{l}\text { Supports Program Offices } \\
\text { through their functional } \\
\text { competencies, contracts } \\
\text { Technical points of contact } \\
\text { on programs } \\
\text { Embedded employees with } \\
\text { Program Offices }\end{array}$ & $\begin{array}{l}\text { Competencies (1.0-8.0) } \\
\text { Contracts } \\
\text { Technology Transfer Office (TTO)/ } \\
\text { SYSCOM Security Cooperation Office } \\
\text { (SSCO) }\end{array}$ \\
\hline $\begin{array}{l}\text { Program } \\
\text { Offices }\end{array}$ & $\begin{array}{l}\text { Manages the acquisition, } \\
\text { deployment and support of } \\
\text { the technology products } \\
\text { and systems } \\
\text { Technical experts }\end{array}$ & $\begin{array}{l}\text { program manager warfare (PMW) } \\
\text { program manager ships (PMS) } \\
\text { program manager air (PMA) }\end{array}$ \\
\hline $\begin{array}{l}\text { Other } \\
\text { Commands }\end{array}$ & $\begin{array}{l}\text { Acquire and support } \\
\text { systems for the fleet } \\
\text { Manage foreign sales for } \\
\text { their platforms }\end{array}$ & $\begin{array}{l}\text { Naval Supply Systems Command (NAVSUP) } \\
\text { weapon systems support (WSS) } \\
\text { U.S. Army communications-electronic } \\
\text { command (CECOM) } \\
\text { U.S. Army PEO Missile \& Space } \\
\text { Naval Education and Training Security } \\
\text { Assistance Field Activity (NETSAFA) } \\
\text { Defense Information System Agency (DISA) }\end{array}$ \\
\hline $\begin{array}{l}\text { Executing } \\
\text { Activities }\end{array}$ & $\begin{array}{l}\text { Product and service } \\
\text { providers }\end{array}$ & $\begin{array}{l}\text { Army and Navy Working Capital Fund } \\
\text { Organizations } \\
\text { Industry Contractors and Sub Contractors } \\
\text { Federally Funded Research and Development } \\
\text { Centers (FFRDC) }\end{array}$ \\
\hline
\end{tabular}




\section{B. GOVERNANCE}

Those stakeholders that fall into the Governance category represent the top of the Chain of Command. Comprised of several layers, they are the decision authorities over acquisition including FMS/CP. With varying breadths of reach and influence as well as differing purposes, the objectives of the organizations at governance level are all closely related. They strive to legitimately implement, ensure and regulate the acquisition process throughout the highest levels of government down to the commands in the most efficient manner possible. Minimizing total ownership cost, rapidly fielding capabilities and developing their workforces are examples of their strategic goals. Throughout the DOD acquisition framework, the stakeholders in charge of governance are the overarching leaders of the process and their influence is prevalent at every stage.

\section{POLICY MAKERS}

The Policy Makers establish and define the rules which all DOD acquisition participants must follow. They establish policies impacting security assistance including FMS/CP and are the authority for which products/capabilities can be exported. Organizations such as DSCA, Navy IPO and the National Security Agency are responsible for ensuring that sales to our foreign partners are always in the interest of the U.S. government (USG) and compliant with established release and disclosure guidelines. From the foreign partner request to the official USG response through completion, they are accountable for ensuring sales are executed in compliance with statute and regulation. Policy Maker stakeholders are also very much involved in the entire DOD acquisition framework since they are involved at every stage in the life cycle of any given sale.

\section{USG CUSTOMERS}

USG Customers represent a major driving force in security assistance. It is from these stakeholders that the majority of the interoperability and capability requirements for our foreign partners are established. Unified Combatant Commands (UCC)/(COCOMS) such as central command (CENTCOM) and Europe Command (EUCOM) and other regional COCOMs as well as their Naval component commands and Fleet Commanders 
make up this group of stakeholders. Their main mission is to conduct military operations in their area of responsibility based on military strategies and cooperation plans. In domestic DOD acquisition, they are the customer and end user. They also, however, establish requirements for foreign nation capabilities and equip and train non-traditional foreign partners as part of their mission. They do this with a focus on achieving the strategies articulated in the Theater Security Cooperation Plans and the required mission. The military commands at this level are interested in receiving authorized and released products/capabilities that support their strategy, that work, and can be fielded quickly. They also help coordinate, communicate and endorse what countries are asking for and what requirements are being requested. Within the DOD acquisition framework the USG customers identify requirements and constantly want to understand what's available and what's in the pipeline and at the same time understand the laws and processes within security assistance in order to execute the mission.

\section{E. EMBASSY TEAMS}

Closely related to our USG Customers, another type of USG stakeholder exists within each foreign partner's nation. Usually, based out of, or affiliated with, the U.S. Embassy, these in-country teams are called Security Cooperation Organizations that can include Department of State and Defense Department personnel. Their interests include understanding the requirements and solution alternatives for military capabilities and endorsing and having awareness of foreign requests for capability as well as end use monitoring. Their influence in the DOD acquisition cycle is mostly in the beginning prior to Milestone A when user needs are being determined and aligning them with technology opportunities and resources.

\section{F. FOREIGN CUSTOMER}

Our Foreign Customer stakeholders represent the Non-U.S. nations that procure and use U.S. military products and systems or receive training and other support. They are in addition to the traditional USG customer in DOD acquisition. Made up of coalition partners and other foreign, sometimes non-traditional governments, this stakeholder is the end user within FMS/CP. Their interests range from self-defense, counter-terrorism, anti- 
piracy, border control, protecting natural resources and humanitarian missions. They have a desire to obtain interoperable systems to effectively operate and communicate with U.S., themselves and other partners. Just as most customers, they are very conscious of their budgets and schedules and how they are managed in order to obtain the capabilities they require. In some cases they only require a better understanding of the basic concepts of the military capabilities available to them. From the DOD acquisition framework perspective, foreign customers traditionally have not had much influence throughout the phases due to a lack of early consideration.

\section{G. SYSTEMS COMMANDS}

System Commands are the major capability aligned acquisition commands. Their main focus is to support the Program Offices through their functional competencies. They provide resources to programs, establish common practices and provide qualified personal to the Program Offices who represent competencies such as comptroller, contracts, engineering, counsel, human resources, program management, technology transfer (disclosure) and security cooperation.

\section{H. PROGRAM OFFICES}

Program Offices manage the acquisition, deployment and support of technology products and systems. They contain the technical experts who are experienced with the development of the capabilities and/or the integration into military platforms or sites. With regard to FMS/CP, the Program Offices either assign personnel directly to support FMS/CP or may be entirely dedicated to providing FMS and coordinate with system/platform Program Offices to identify and deliver capability.

\section{EXECUTING ACTIVITIES}

In direct support to the Program Offices are the Executing Activities stakeholders. They are the product and service providers that the Program Offices enter into USG-toUSG agreements with such as Army and Navy working capital funds (WCF) engineering centers, contracts with industry and sometimes Federally Funded Research and Development Centers (FFRDC). From the USG Systems Center and FFRDC perspective, 
their goal is to efficiently and effectively provide technical services and capabilities to the fleet while covering their operating costs. From Industry's perspective their goal is mainly to operate a successful business in support of the USG acquisition objectives.

\section{J. OTHER COMMANDS}

Finally, stakeholders also exist at Other Commands outside of the traditional Systems Commands. These Other Commands can vary in what they provide and/or support for the fleet. In some cases they may also manage foreign sales for their platforms/capabilities. Several examples include Naval Supply Systems Command Weapon Systems Support (NAVSUP WSS), U.S. Army communications-electronic command (CECOM) U.S. Army PEO Missile \& Space, Naval Education and Training Security Assistance Field Activity (NETSAFA) and Defense Information System Agency (DISA). The significance of this group is that in many areas they hold the key to providing an end-to-end solution or service.

\section{K. STAKEHOLDER SUMMARY}

Figure 1 is provided as a high level interface diagram from the perspective of the FMS/CP community. The figure shows the breadth of stakeholder involvement and with the exception of a few, the stakeholder groups should look familiar to the domestic Program Office. This chapter's focus was on identifying the multiple stakeholders who influence, are impacted by or have an interest in FMS/CP during the life cycle of a domestic product and/or service. Descriptions were provided to explain the unique entities within the various stakeholder levels as well as their expectations in order to gain an understanding of the players in the FMS/CP arena. Of importance in this chapter was the element that the foreign partner is in addition to the traditional USG customer in DOD acquisition. 


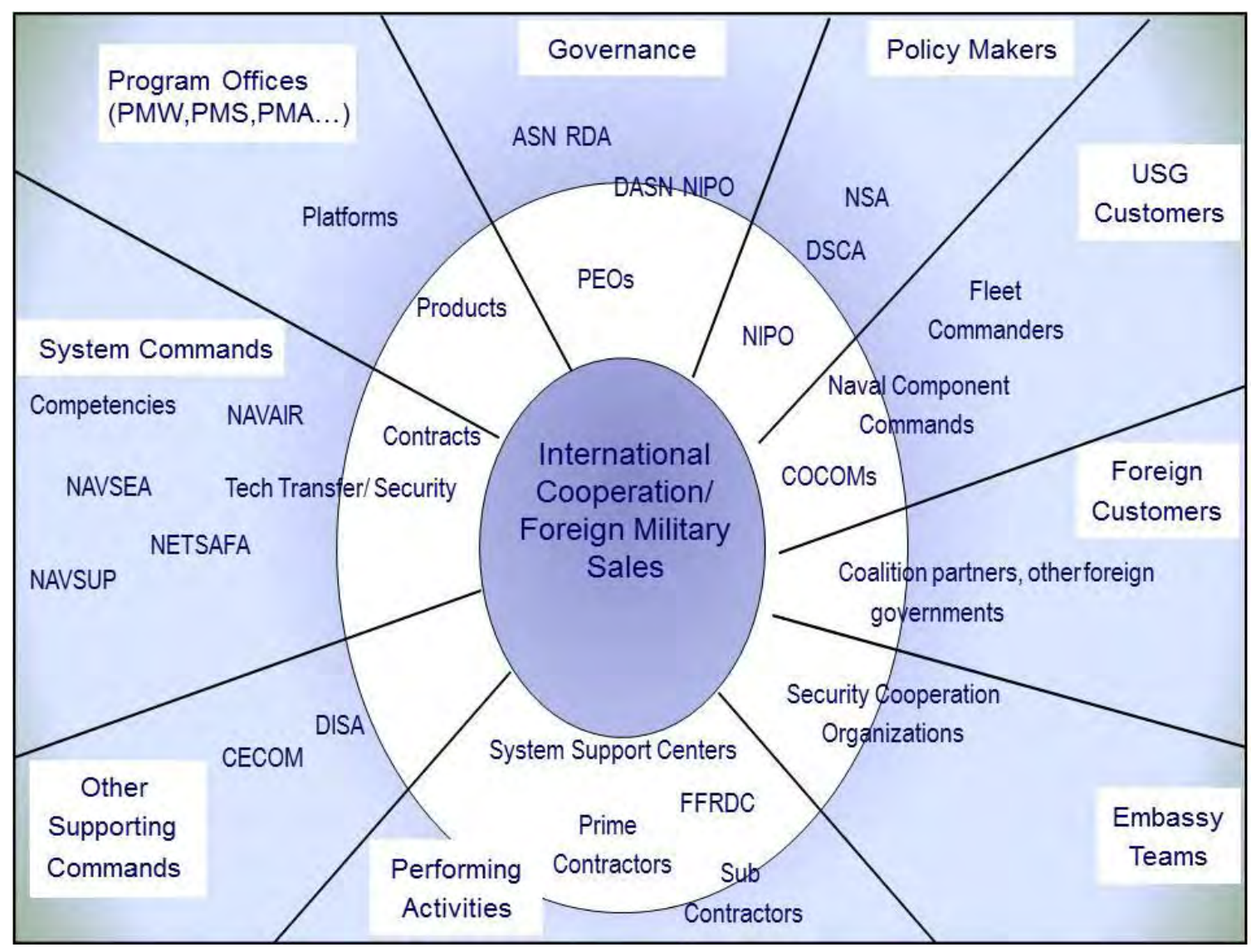

Figure 1. FMS/CP Stakeholders 
THIS PAGE INTENTIONALLY LEFT BLANK 


\section{PROGRAM EXAMPLES}

\section{A. INTRODUCTION}

The following sections provide specific U.S. DOD acquisition program examples where international consideration was done early, middle, late or not at all in their acquisition life cycles. Programs from both the U.S. Navy and U.S. Army are examined and include platforms, systems and individual capabilities. The data presented includes program description, international involvement and then strengths, weaknesses, opportunities and threats (SWOT) analysis of cost, schedule and performance relative to the program's level of international involvement.

\section{B. GLOBAL COMMAND \& CONTROL SYSTEM-JOINT}

\section{Program Description}

The Global Command \& Control System-Joint (GCCS-J) is a DOD major information technology (IT) investment and designated as an ACAT 1AC Major Automated Information System (MAIS) Special Interest program developed by the Defense Information Systems Agency (DISA). ${ }^{7}$ DISA is a DOD Combat Support Agency that provides, operates, and assures command and control (C2), information sharing capabilities, and a globally accessible enterprise information infrastructure in direct support to joint Warfighters, National level leaders, and other mission and coalition partners across the full spectrum of operations. ${ }^{8}$

\section{System Description}

GCCS-J provides "vital connectivity to systems used to plan, execute and manage military operations for both joint and multinational operations. The GCCS-J service fuses select $\mathrm{C} 2$ capabilities into a comprehensive, interoperable system by exchanging imagery, intelligence, status of forces, and planning information." GCCS-J is a command, control,

7 "GCCS-J Program Control Acquisition Management Support Services," last modified October 21, 2009 https://www.fbo.gov.

8 “GCCS-Joint," accessed on September 15, 2014, http://www.disa.mil/Services/Command-andControl/GCCS-J. 
communications, computer, and intelligence (C4I) system for achieving full spectrum dominance, consisting of hardware, software, procedures, standards, and interfaces that provide a C2 capability to the Commander-in-Chief (CINC), Secretary of Defense (SeCDeF), National Military Command Center (NMCC), combatant commanders (CDRs), joint force commanders, and service component commanders. It is a suite of mission applications fusing select capabilities into a comprehensive, interoperable system by exchanging imagery, intelligence, status of forces, and planning information. GCCS-J is the principal foundation for dominant battle space awareness, providing an integrated, near real-time picture of the battle space necessary to conduct joint and multinational operations. It offers vital connectivity to the systems the joint warfighter uses to plan, execute, and manage military operations." 9

GCCS-J is a full spectrum C2 system capable of supporting joint and multinational operations. GCCS-J is also the foundation for other variants developed and used by the U.S. Army, Air Force, Navy and Coast Guard. These variants, based on GCCS-J, include capabilities that are specific to the individual services and their missions.

\section{GCCS-J International Involvement}

GCCS-J is an example of a program where international consideration was included early in its acquisition life cycle. As indicated above, DISA considers coalition partners and multinational operations in the scope of requirements satisfied by GCCS-J. As per Mr. Robert Randle of DISA GCCS-J PO in 2009, "GCCS-J is a critical partner in Allied and Coalition Operations and places emphasis toward that during development." International users include NATO, Canada, Sweden, Italy, Denmark, France and the Czech Republic to name a few. As with most international applications, tailoring for scalability and releaseability varies depending on the partner. DISA will either make these modifications or allow other DOD POs to use a releasable baseline to integrate the

9 “GCCS-Joint," accessed on September 15, 2014, http://www.disa.mil/Services/Command-andControl/GCCS-J. 
scalability. In both instances, DISA provides support of the product to the international customer and/or the integrating PO.

\section{SWOT}

Strengths, weaknesses, opportunities and threats as they pertain to the GCCS-J PO's level of international consideration in the areas of cost, schedule and performance are as follows:

- Strengths:

- Cost: Able to use both domestic and international funding to support the product as a whole.

- $\quad$ Schedule: Able to abbreviate delivery schedules by exploiting initial baseline(s) and scaling from there as opposed to developing from the ground up

- Performance: Able to accommodate both domestic and international C4ISR requirements

- Weaknesses:

- $\quad$ Cost: Higher operating costs to support international components

- $\quad$ Schedule: Multiple schedules increase multiple opportunities for schedule risks

- $\quad$ Performance: Limited interoperability testing opportunities as a result of coordination complexity

- Opportunities:

- Cost: Diversifies system to meet changing and competing domestic and international requirements

- $\quad$ Schedule: Able to potentially shorten future delivery timeframes by developing fewer baselines for multiple customers

- $\quad$ Performance: Era of expanding coalition involvement and increase U.S. reliance on allies provides more opportunities to meet and use international capability requirements

- Threats:

- Cost: Investment in international requirements could be wasted if international interests decline or radically change

- $\quad$ Schedule: Delivery schedules could be jeopardized if domestic and international requirements compete with each other for the same resources 
- $\quad$ Performance: Information assurance across a broader spectrum of customers could open up system vulnerabilities

\section{GLOBAL COMMAND \& CONTROL SYSTEM-MARITIME (GCCS-M)}

\section{Program Description}

GCCS-M is based on GCCS-J and is the USN variant that adds specific naval functionality and scalability to support its command structure across numerous platform type, sizes and missions. "GCCS-M provides maritime commanders at all echelons with a single, integrated, and scalable C2 system. GCCS-M fuses, correlates, filters, maintains, and displays location and attribute information on friendly, hostile, and neutral land, sea, and air forces, and integrates this data with available intelligence and environmental information to support command decisions." 10

\section{GCCS-M International Involvement}

GCCS-M is an example of a program where international consideration was not included, but deferred, in its acquisition life cycle. One of the GCCS-M missions is maritime coalition interoperability. As a result of this, GCCS-M can be tailored and released to individual coalition partners to fulfill this mission requirement. The requirement for a specific coalition partner to obtain the GCCS-M capability, in most cases, stems from the COCOM interoperability requirement for that specific nation's navy.

To satisfy this requirement, the request from the foreign partner, with the COCOM endorsement is submitted to DSCA and forwarded to NIPO for tasking. PEO C4I's international C4I integration PO (PMW 740) provides a "Quick look" back to NIPO, vetting the request for pricing and availability to the GCCS-M PO and for disclosure to the Systems Command's security office. An "offer" is prepared and submitted through NIPO and DSCA to the purchasing nation for acceptance and implementation. Once implemented, funds are made available and PMW 740 can begin

10 "Global Command and Control System-Maritime (GCCS-M)," accessed on September 15, 2014, http://www.public.navy.mil/spawar/productsServices/Pages/GlobalCommandandControlSystemMaritime(GCCS-M).aspx 
the task of procuring, developing, integrating, testing, installing, training and supporting the GCCS-M implementation for the purchasing nation.

Another possible way to satisfy the foreign partner's request is for PEO C4I to route the request to their Navy Command and Control PO (PMW 150) which is the PO responsible for GCCS-M. However, In order to meet this maritime coalition interoperability requirement, the GCCS-M PO allows other entities, within their SYSCOM, to build integrate and release individual builds for specific coalition partners. The GCCS-M PO, therefore, has focused its efforts on the task of building and releasing its own three (3) USN command structure builds. As a result, the GCCS-M PO limits its international consideration to the disclosure level and relies on PMW 740 to deliver the requested capability to the purchasing nation.

\section{SWOT}

Strengths, weaknesses, opportunities and threats as they pertain to the GCCS-M PO's level of international consideration in the areas of cost, schedule and performance are as follows:

- Strengths:

- Cost: Lowers operating costs by limiting the number of customers

- $\quad$ Schedule: Single customer focus limits schedule permutations

- Performance: Disclosure Authority responsible for determining final baseline of capabilities based on releaseability

- Weaknesses:

- Cost: Resources from international involvement cannot be leveraged to potentially benefit domestic development

- Schedule: International customer pressure on domestic release schedules

- $\quad$ Performance: Limited or no influence on system integration efforts for international customers on their own system baseline

- Opportunities:

- Cost: Domestic focus should increase probability of being within budget 
- Schedule: Domestic focus should increase probability of being on time

- $\quad$ Performance: Limits complexity in an already complex capabilities set

- Threats:

- Cost; Lack of international consideration removes opportunities that could sustain the PO during a period of DOD reductions

- Schedule: Challenges to meeting the demanding domestic schedules could cause international partners to look to other C4ISR products

- $\quad$ Performance: Narrowly focusing on a single customer excludes consideration of information assurance (IA) postures/ vulnerabilities and information sharing challenges in the international arena

\section{FIGHTER/ATTACK (F/A)-18}

\section{Program Description}

The F/A-18 entered testing in 1979 and operational service in 1983 with the U.S. Navy and Marine Corps and is still in operation as of the date of this paper. Numerous variants in the platform were developed to support 1 and 2 seat configurations, multiple mission packages and upgrades. The F/A-18 is described as follows:

The McDonnell Douglas (now Boeing) F/A-18 Hornet is a twin-engine supersonic, all-weather carrier-capable multirole combat jet, designed as both a fighter and attack aircraft (F/A designation for fighter/attack). Designed by McDonnell Douglas and Northrop, the F/A-18 was derived from the latter's YF-17 in the 1970s for use by the United States Navy and Marine Corps. The Hornet is also used by the air forces of several other nations. The U.S. Navy's Flight Demonstration Squadron, the Blue Angels, has used the Hornet since 1986. ${ }^{11}$

Back in the early 1970 s, the original requirement for the F/A-18 stemmed from the need for a multirole aircraft to replace the A-4, A-7 and F-4 platforms as well as to work in conjunction with the F-14. During this same period, numerous industry partners such as McDonnell Douglas, Northrop and General Dynamics participated in U.S. Air

11 Wikipedia, s.v. "F/A-18," last modified September 12, 2014. http://en.wikipedia.org/wiki/McDONnell_Douglas_F/A-18_Hornet 
Force (USAF) competitions for a new airframe. The U.S. Navy, not satisfied with the USAF competition results, requested that McDonnell Douglas and Northrop together come up with a new design. Both companies worked together and came up with the original F-18 platform sharing the component manufacturing efforts. McDonnell Douglas became the prime for the naval versions and Northrop became the prime for what was hoped to be an exportable version. ${ }^{12}$

\section{F/A-18 International Involvement}

F/A-18 is an example of a program where international consideration was not a driving force at the beginning but was included later in its acquisition life cycle at least by the U.S. Navy. Industry, however attempted to consider it early. The exportable version, called the F-18L did not take hold with the international community and never went into mass production. McDonnell Douglas continued to work with the U.S. Navy and through FMS sales (except for Canada which was DCS) delivered variants to the Royal Australian Air Force (1984), Canada (1982), Finland (1995), Kuwait (1991), Malaysia (1997) Spain (1985), and Switzerland (1996). ${ }^{13}$

In large weapons systems acquisitions such as the F/A-18 it is common for Industry to own the export and design rights such as McDonnell Douglas did after buying Northrop out of the rights for the F-18L. Owning these rights allows the company to essentially market the platform to foreign countries that can be exported to as deemed by the Department of State. DCS and FMS are both options but in the case of the F/A-18 the majority of international sales were done via FMS. The international sales revenues to the seven (7) countries that purchased F/A-18s was over $\$ 7$ billion which ultimately reduced the cost of new aircraft to the U.S.. ${ }^{14}$

12 Wikipedia, s.v. "F/A-18," last modified September 12, 2014. http://en.wikipedia.org/wiki/McDONnell_Douglas_F/A-18_Hornet

13 Wikipedia, s.v. "F/A-18," last modified September 12, 2014. http://en.wikipedia.org/wiki/McDONnell_Douglas_F/A-18_Hornet

14 "F/A-18 FMS manager's efforts result in \$1 billion in savings," last modified April 30, 2013, http://www.navair.navy.mil/index.cfm?fuseaction=home.NAVAIRNewsStory\&id=5326. 


\section{SWOT}

Strengths, weaknesses, opportunities and threats as they pertain to the F/A-18 program's level of international consideration in the areas of cost, schedule and performance are as follows:

- $\quad$ Strengths:

- Cost: Cost of new aircraft to U.S. was reduced as a result of international sales

- Schedule: Able to maintain aggressive delivery schedules by exploiting a single baseline design and adding variants on top

- Performance: Additional resources from international sales allowed multiple variants whose innovations benefited all customers

- Weaknesses:

- Cost: Higher number of engineering and support elements and associated operating costs to support international configurations

- $\quad$ Schedule: Multiple schedules increase multiple opportunities to miss

- $\quad$ Performance: Competing domestic and international requirements could result in undesirable tradeoffs for stakeholders

- Opportunities:

- Cost: Diversification of platform to meet domestic and international requirements which could keep industry partner production lines open as the demands of each customer base change

- Schedule: Potential ability to align schedules of both customer bases

- $\quad$ Performance: Increased interoperability and support infrastructure with allies

- Threats:

- Cost: Investment in international requirements could be wasted if international interests decline or radically change

- $\quad$ Schedule: Delivery schedules could be jeopardized if domestic and international demands conflict or compete

- $\quad$ Performance: Releaseability and/or export restrictions could limit platform capabilities and potentially force re-design if not fully considered before entering into agreements 


\section{E. AIR TRAFFIC NAVIGATION, INTEGRATION, AND COORDINATION SYSTEM (ATNAVICS)}

\section{System Description}

ATNAVICS provides air traffic services (ATS) at terminal airfields, landing sites or zones within the division, corps and echelons above corps (EAC) areas of operation. The controller stations and communication equipment are installed in an S-788 shelter which is typically mounted on the prime mover, a high mobility multipurpose wheeled vehicle, (HMMWV). ATNAVICS includes the following subsystems: secure voice communications package; airport surveillance radar (ASR); precision approach radar (PAR); secondary surveillance radar/identify friend or foe (SSR/IFF); two multimode display units; self-contained environmental control equipment; power generation equipment and required spares and support equipment. The capability of being air transportable with roll-on/roll-off capability on a $\mathrm{C}-130$ or larger aircraft allows the ATNAVICS system to be rapidly deployed and functional world-wide. The complete deployable package includes the operation shelter, the sensor equipment (ASR/PAR/SSR/IFF), generators, trailers, personal gear for technicians, placement and setup equipment, cables and other ancillary equipment.

\section{Program Description}

ATNAVICS is an Army and Marine Corps ACAT III program that was acquired as a non-developmental item (NDI) to replace the AN/TSQ-71 system, which includes the AN/TPN-18, a tactical PAR system. The AN/TPN-18 was bulky, required excessive time to install, and was extremely difficult to maintain due to its outdated technology components. The ATNAVICS requirement was officially documented in an operational requirements document (ORD), dated 29 November 1992, updated and re-validated on 10 September 1999.

A competitive cost plus incentive fee contract was awarded to Raytheon in 1995 to conduct engineering and manufacturing development (EMD) for the ATNAVICS. After contract modifications, cost overruns and delays, the contract was modified in 1998 to complete the EMD effort and capped at \$26.1M. One prototype system was built 
with developmental testing and operational testing (DT/OT) conducted at FT Huachuca and FT Campbell in fiscal year 1999 (FY99). Through March 2005, the government exercised hardware options to procure twenty-four ATNAVICSs (two of which were funded by and are for the Marine Corps). Production was completed in fiscal year (FY) 13 with a total of fifty-four ATNAVICSs produced, thirty-nine for the Army and fifteen for the Marine Corps.

\section{International Involvement}

Air Traffic Control provided by the ATNAVICS is international in capability and interoperability by its nature. The international interoperability is achieved through the choice of radios, power requirements, and IFF equipment (TPX-56) as well as flexibility in assignment of radar frequencies and was considered in the earliest requirements for ATNAVICS. The ATNAVICS has a data network connection to the TAIS using the international ASTERIX standard for radar data which allows for potential porting of information to international partners.

There have been no significant issues identified with international capability or interoperability of the system in use by the Army or Marine Corps. However, as a result of the NDI effort, re-use of government furnished equipment established the technological foundation for the ATNAVICS. Transmit/receive modules (TRM) used in the PAR portion of the system came from, and are still used in, the THAAD Radar system. These subsystems/component and are export controlled. For the foreseeable future, the Army and Marine Corps will be restricted from FMS agreements and Raytheon will be unable to execute DCS agreements. Developmental cost and schedule was gained at the expense of system exportability.

Strengths, weaknesses, opportunities and threats as they pertain to the ATNAVICS level of international consideration in the areas of cost, schedule and performance is as follows: 


\section{SWOT}

- $\quad$ Strengths:

- $\quad$ Cost: Potentially allow for increased quantity buys and reduced individual system costs. Potential for increased competition may decrease overall development, procurement and sustainment costs

- $\quad$ Schedule: None

- $\quad$ Performance: None. It is assumed that there were no existing TMR technologies available from international sources

- Weaknesses:

- Cost: International involvement excludes the opportunity for NDI of critical subsystems. Developmental costs of technology to meet the performance requirements would be significantly increased

- Schedule: International involvement increases the EMD schedule significantly

- $\quad$ Performance: Holding with the assumption that no technology is available from international sources, performance sacrifices would need to be made for the allowance of international participation

- Opportunities:

- Cost: Potential capability and technology insertion could be cost shared with foreign governments which would reduce the future cost of upgrades

- $\quad$ Schedule: International purchases could provide opportunities for schedule flexibility by allowing to better manage long term production rates

- $\quad$ Performance: None

- Threats:

- Cost: International involvement increases cost estimates for development and production and simultaneously adds cost risk to the program

- $\quad$ Schedule: Significantly increased schedule would almost certainly be a result of international involvement

- Performance: Some, if not significant, reduction on developed performance would be anticipated with international involvement 


\section{F. APACHE ATTACK HELICOPTER (AH-64)}

\section{System Description}

The Apache is the U.S. Army's primary attack helicopter. Entering into service in 1982 and currently being built by Boeing in Mesa Arizona, it is now fielded in its third Type designation known as the AH-64E Apache Guardian ${ }^{15}$. Replacing the AH-1 Cobra, which had been the primary U.S. Army Attack Helicopter since the Vietnam War, the Apache maintains the tandem seating configuration of the Cobra but incorporates a twin engine driven, four bladed design with tail/main wheel type landing gear. The Apache brings many capability improvements to the battle over previous systems such as; improved weapons systems, improved payload capacity, improved speed and range, improved day/night vision and targeting sensors, and will soon have manned/unmanned teaming ability. ${ }^{16}$

To meet a broader spectrum of missions within the context of the Apaches role as a Close Combat Attack (CCA) aircraft, it can be configured in multiple variations using the customizable weapons loading attached to hard point connections and interfaces on the stub-wings. Weapons systems typically include, in varying amounts; Hellfire Missiles, Hydra 70 Aerial Rockets and $30 \mathrm{~mm}$ rounds for the nose turret mounted Chain Gun. Additional systems may include Stinger or AIM-9 air-to-air missiles, Sidearm antiradiation missiles, or external fuel tanks. ${ }^{17}$

The Apache is a proven weapon system with top in its class capabilities. Operational successes include; extensive deployment to Operation Desert Storm where they destroyed key Iraqi anti-aircraft detection systems and nearly 300 enemy tanks, key roles in Bosnia and Kosovo during the 1990s, and continued persistent operations in Afghanistan since 2001.

15 Wikipedia, s.v. "Boeing AH-64 Apache," last modified September 14, 2014. http://en.wikipedia.org/wiki/Boeing_AH-64_Apache.

16 Derived from Wikipedia, s.v. "Boeing AH-64 Apache," last modified September 14, 2014. http://en.wikipedia.org/wiki/Boeing_AH-64_Apache.

17 Ibid. 


\section{Program Description}

The Apache is an ACAT I program, managed by PM-AH (Attack Helicopter), under PEO Aviation at Redstone Arsenal in Huntsville Alabama. The first helicopter rolled off the Mesa Arizona based Hughes Helicopter facility floor in 1983. By 1997, Hughes Helicopter had been bought by McDonnell Douglas and then merged to become part of The Boeing Company. Original versions of the AH-64A were costing the Army about \$7M flyaway and about $\$ 13.9$ in Per Unit Average Costs ${ }^{18}$. The Defense Acquisition Board (DAB) approved the development of an upgraded Apache, the AH64D Longbow which included the addition of the mast mounted Millimeter Microwave Radar Identification and Targeting System along with several other upgrades that, after a head to head evaluation, were demonstrated to have a $700 \%$ survivability increase and a $400 \%$ lethality increase ${ }^{19}$. Full Rate Production of the Longbow Apache was approved in 1996 with a target production total of 232 AH-64Ds.

\section{International Involvement}

The Apache is produced, tested, operated and supported with international involvement throughout. Various aerospace firms from around the world produce components of the Apache for Boeing. One of the largest is AgustaWestland, an Italian and United Kingdom merged company, builds several components for the Boeing produced variant and for a British Army Apache variant. This British variant is known as the AgustaWestland Apache and is assembled from kits purchased from Boeing under export license. The kit is based on the AH-64D Block I but has changes that support operation from Royal Navy vessels including more powerful engines, and folding rotor blades. The United Kingdom also maintains a Cooperative Development agreement with the U.S. where new technology development can be cost/benefit shared between both governments. This includes CET and FCT where test efforts, data and evaluations are shared. Korea Aerospace Industries is currently the sole manufacturer of the fuselage for the entire Apache production effort. Both the AH-64A and the AH-64D have been sold

18 Wikipedia, s.v. "Boeing AH-64 Apache," last modified September 14, 2014. http://en.wikipedia.org/wiki/Boeing_AH-64_Apache.

19 Ibid. 
as-is or modified and exported to a long list of foreign governments through either FMS and/or DCS ${ }^{20}$. A recent look at Wikipedia revealed that 13 countries, besides the U.S. and U.K. operate the Apache helicopter currently or are planning to in the near future including; Egypt, Greece, India, Indonesia, Israel, Japan, Kuwait, Netherlands, Saudi Arabia, Singapore, South Korea, Taiwan and United Arab Emirates.

Various country specific configurations are typically accommodated for on the production line, or through post-delivery installation/integration of unique subsystems such as communication suites, Radar, Missile, Laser, or Infrared threat detection systems. This process has similarities to current automobile manufacturing in that various options can be added or omitted during the production process to tailor the final production unit for the specific customer.

Foreign access to computer source code is highly restricted, which limits the ability for other countries to develop new subsystems that would need to interoperate with the Apache's operating systems main interface backbone, the 1553 Bus. In modern aviation systems, almost all electronic systems interface with the Bus. Not having the ability to independently develop unique subsystems that can be fully integrated into the Apache has caused concern with several foreign governments.

\section{SWOT}

Strengths, weaknesses, opportunities and threats as they pertain to the Apache program level of international consideration in the areas of cost, schedule and performance is as follows:

- $\quad$ Strengths:

- $\quad$ Cost: Enables reduced per unit costs due to increased quantity buys

- $\quad$ Schedule: Provides additional stability to production schedule with ability to maintain optimum production rate

- $\quad$ Performance: Additional capabilities developed and tested through the Cooperative Development Agreement are cost and risk shared. This allows for potential system performance improvement that

20 Wikipedia, s.v. "Boeing AH-64 Apache," last modified September 14, 2014. http://en.wikipedia.org/wiki/Boeing_AH-64_Apache. 
otherwise may not be affordable. The additional firepower and war fighting capability of the Apache being distributed to our Allies has increased the lethality of the total Coalition. Internationally shared systems and support infrastructure can result in an overall reduced life cycle sustainment cost for all users

- Weaknesses:

- $\quad$ Cost: PMO staffing is required to be maintained at a higher level to support ongoing CD/FMS, and to a minimal extent, the DCS efforts. Failure of FMS agreements to be executed after the budgeting process causes a potential double hit to per unit cost

- Schedule: Higher than expected demand by FMS and/or DCS could place U.S. Apache schedule at risk due to competing demands on the production line

- $\quad$ Performance: Added complexity to an already complex platform

- Opportunities:

- Cost: Continued FMS/DCS efforts can potentially improve economies of scale and result in further per unit cost of the Apache. FMS sales can potential offset cost of future purchase of upgraded Apaches for the U.S. Army fleet

- $\quad$ Schedule: International purchases could provide opportunities for schedule flexibility and allow better managing of long term production rates

- $\quad$ Performance: Increase user base can potential reveal opportunities for performance improvement. Increase international partnerships open opportunities for foreign technology that otherwise may not be available

\section{- Threats:}

- $\quad$ Cost: Uncertainty of Foreign Country commitments, coupled with U.S. funds programming lead time creates cost risk and/or quantity of procurement risk

- $\quad$ Schedule: Potential for international cooperation/FMS/DCS adds criticality to the Apache Program Protection Plan and requires additional scrutiny with Information Assurance concerns. This potentially puts risk on the schedule

- Performance: Certain technologies may not get integrated on or into the Apache due to concern about exportability of the overall system. Some potential performance improvement opportunities could be sacrificed to maintain attractiveness to the foreign market 


\section{G. OTHER PROGRAM EXAMPLES}

The programs and systems discussed above are just a few examples of when and where international consideration can occur in an acquisition life cycle. There are numerous examples of early consideration such as the Multifunctional Information Distribution System (MIDS), advanced extremely high frequency (AEHF) and the Joint Strike Fighter (JSF) where international consideration and partnerships were included at the inception. An example of international consideration after conception is the Mobile User Objective System (MUOS) and the plans for a coalition waveform via a cooperative program among several nations. Too numerous to mention are the programs that do not take international military partners into consideration due to barriers such as Information Assurance and protected technologies. Chapter V will discuss these barriers in more detail. 


\section{ANALYSIS}

\section{A. ANALYSIS OF PROGRAM RESEARCH}

In the previous chapter, five DOD programs were examined to determine their individual strengths, weaknesses, opportunities and threats pertaining to the level of international consideration in their acquisition cycles. Examples of programs that considered international requirements early included GCCS-J and Apache. Examples of programs that began as domestic-only and branched out to the international component included the F/A-18 and GCCS-M programs. Finally, the ATNAVICS program was examined as an example of a program that could not capitalized on international consideration. The following list summarizes the programs research by name, ACAT and service capability.

- $\quad$ GCCS-J-ACAT 1 Joint Command and Control System

- $\quad$ GCCS-M -ACAT 1 Navy Command and Control System

- $\quad$ F/A-18-ACAT 1 Navy Platform

- $\quad$ ATNAVICS-ACAT III Army Air Traffic Service

- $\quad$ Apache-ACAT I Army Platform

\section{SWOT Comparison}

Table 2, located at the end of this section, presents the SWOT information from Chapter IV in a format that compares the SWOT elements; cost, schedule and performance side-by-side for all five programs.

\section{a. Cost SWOT Comparison}

Cost strength similarities among programs include cost sharing for both services and per unit costs. Cost weakness similarities among programs include added program complexity requiring additional cost and potential problem of timing alignment for domestic and international budget actions. Cost opportunity similarities among programs include program diversification for the potential benefit of economies of scale, industry base support and cost sharing. Cost threat similarities among programs include increased cost risk due to unaligned schedules and changing or uncertain international 
requirements. The differences among the programs researched in cost SWOT occurred in the GCCS-M program whose decision as a program office to defer the international work to other organizations and with ATNAVICS as a result of using non-releasable NDI in the solution.

\section{b. Schedule SWOT Comparison}

Schedule strength similarities among programs include reuse of domestic baselines to reduce development schedules, schedule alignments and production line stability. Schedule weakness similarities among programs include the increased complexity and risk as a result of added international stakeholders. Schedule opportunity similarities among programs include schedule alignment and production stability. Schedule threat similarities among programs include added complexity risk and competing schedules resulting in delays to domestic and/or international timing requirements. The differences among the programs researched in schedule SWOT again were with GCCS-M and in most areas benefited the program due to a decrease in risk due to few stakeholders than the programs when compared to the programs who considered international requirements. Another difference noted was with the major platform programs and the production stability benefits due to the inclusion of international procurements.

\section{c. Performance SWOT Comparison}

Performance strength similarities among programs include the potential for reduced life cycle sustainment cost for all users and the added international stakeholder requirements potentially broaden innovation and capability set. Performance weakness similarities among programs include added complexity that increases risk in performance and the potential for competing requirements that force undesirable tradeoffs. Performance opportunity similarities among programs include increased user base, opening new doors in DOD acquisition to meet and utilize international capability requirements and increased interoperability and support infrastructure with allies. Performance threat similarities among programs include information assurance concerns, release and exportability barriers. Some differences among the programs researched in 
performance SWOT were revealed in GCCS-M and ATNAVICS as a result of those programs not involving the international component. Potential opportunities to capitalize on the international influence on possible performance enhancements were differed by the PO due to competing priorities. Another difference was the limited interoperability testing opportunities for the $\mathrm{C} 2$ systems as a result of coordination complexity.

\section{SWOT Analysis}

Similarities and differences across cost, schedule and performance supported the premise of this research in that when the opportunity exists to consider international requirements the program may be able to benefit. The key however, is the ability to manage the additional risk of added complexity and increased number of stakeholders that international consideration brings to the process. Timing, as it pertains to requirement identification, budget cycles and delivery schedules all have to align as much as possible on both sides in order to effectively control the risk. On top of this, domestic priorities and releaseability can both play a limiting factor even when everything is aligned. GCCS-M is a good example where the domestic and international alignment may have been too far apart for the PO to consider the potential and still meet their domestic priorities. The barrier that the ATNAVICS system hit was with releaseability of NDI which resulted in a nonstarter for international consideration.

Risk acceptance and mitigation in order to leverage international requirements and resources need to be weighed individually by each program. Quantifiable evidence such as actual schedule metrics and budget data were not available for this research effort due to accessibility constraints. However, data such as cost and budget metrics for international consideration should be available internally to most program offices to aid in the decision to pursue or not to pursue. 
Table 2. SWOT Comparison for Cost, Schedule and Performance

\begin{tabular}{|c|c|c|c|c|}
\hline Program & Strengths & Weaknesses & Opportunities & Threats \\
\hline $\begin{array}{l}\text { GCCS-J } \\
\text { Cost }\end{array}$ & $\begin{array}{l}\text { Able to use } \\
\text { both domestic } \\
\text { and } \\
\text { international } \\
\text { funding to } \\
\text { support the } \\
\text { product as a } \\
\text { whole }\end{array}$ & $\begin{array}{l}\text { Higher operating } \\
\text { costs to support } \\
\text { international } \\
\text { components }\end{array}$ & $\begin{array}{l}\text { Diversifies system } \\
\text { to meet changing } \\
\text { and competing } \\
\text { domestic and } \\
\text { international } \\
\text { requirements }\end{array}$ & $\begin{array}{l}\text { Investment in } \\
\text { international } \\
\text { requirements could } \\
\text { be wasted if } \\
\text { international } \\
\text { interests decline or } \\
\text { radically change }\end{array}$ \\
\hline $\begin{array}{l}\text { GCCS-M } \\
\text { Cost }\end{array}$ & $\begin{array}{l}\text { Lowers } \\
\text { operating costs } \\
\text { by limiting the } \\
\text { number of } \\
\text { customers }\end{array}$ & $\begin{array}{l}\text { Resources from } \\
\text { international } \\
\text { involvement are } \\
\text { not available to } \\
\text { potentially } \\
\text { benefit domestic } \\
\text { development }\end{array}$ & $\begin{array}{l}\text { Domestic focus } \\
\text { should increase } \\
\text { probability of } \\
\text { being within } \\
\text { budget }\end{array}$ & $\begin{array}{l}\text { Lack of } \\
\text { international } \\
\text { consideration } \\
\text { removes } \\
\text { opportunities that } \\
\text { could sustain the } \\
\text { PO during a period } \\
\text { of DOD reductions }\end{array}$ \\
\hline F/A-18 Cost & $\begin{array}{l}\text { Cost of new } \\
\text { aircraft to U.S. } \\
\text { was reduced as } \\
\text { a result of } \\
\text { international } \\
\text { sales }\end{array}$ & $\begin{array}{l}\text { Higher number } \\
\text { of engineering } \\
\text { and support } \\
\text { elements and } \\
\text { associated } \\
\text { operating costs to } \\
\text { support } \\
\text { international } \\
\text { configurations }\end{array}$ & $\begin{array}{l}\text { Diversification of } \\
\text { platform to meet } \\
\text { domestic and } \\
\text { international } \\
\text { requirements } \\
\text { which could keep } \\
\text { industry partner } \\
\text { production lines } \\
\text { open as the } \\
\text { demands of each } \\
\text { customer base } \\
\text { change }\end{array}$ & $\begin{array}{l}\text { Investment in } \\
\text { international } \\
\text { requirements could } \\
\text { be wasted if } \\
\text { international } \\
\text { interests decline or } \\
\text { radically change }\end{array}$ \\
\hline $\begin{array}{l}\text { ATNAVICS } \\
\text { Cost }\end{array}$ & $\begin{array}{l}\text { Potentially } \\
\text { allow for } \\
\text { increased } \\
\text { quantity buys } \\
\text { and reduced } \\
\text { individual } \\
\text { system costs. } \\
\text { Potential for } \\
\text { increased } \\
\text { competition } \\
\text { may decrease } \\
\text { overall } \\
\text { development, } \\
\text { procurement } \\
\text { and } \\
\text { sustainment } \\
\text { costs }\end{array}$ & $\begin{array}{l}\text { International } \\
\text { involvement } \\
\text { excludes the } \\
\text { opportunity for } \\
\text { NDI of critical } \\
\text { subsystems. } \\
\text { Developmental } \\
\text { costs of } \\
\text { technology to } \\
\text { meet the } \\
\text { performance } \\
\text { requirements } \\
\text { would be } \\
\text { significantly } \\
\text { increased }\end{array}$ & $\begin{array}{l}\text { Potential } \\
\text { capability and } \\
\text { technology } \\
\text { insertion could be } \\
\text { cost shared with } \\
\text { foreign } \\
\text { governments } \\
\text { which would } \\
\text { reduce the future } \\
\text { cost of upgrades. }\end{array}$ & $\begin{array}{l}\text { International } \\
\text { involvement } \\
\text { increases cost } \\
\text { estimates for } \\
\text { development and } \\
\text { production and } \\
\text { simultaneously } \\
\text { adds cost risk to } \\
\text { the program }\end{array}$ \\
\hline
\end{tabular}




\begin{tabular}{|c|c|c|c|c|}
\hline Program & Strengths & Weaknesses & Opportunities & Threats \\
\hline Apache Cost & $\begin{array}{l}\text { Enables } \\
\text { reduced per } \\
\text { unit costs due } \\
\text { to increased } \\
\text { quantity buys. }\end{array}$ & $\begin{array}{l}\text { PMO staffing is } \\
\text { required to be } \\
\text { maintained at a } \\
\text { higher level to } \\
\text { support ongoing } \\
\text { CD/FMS, and to } \\
\text { a minimal extent, } \\
\text { the DCS efforts. } \\
\text { Failure of FMS } \\
\text { agreements to be } \\
\text { executed after the } \\
\text { budgeting } \\
\text { process causes a } \\
\text { potential double } \\
\text { hit to per unit } \\
\text { cost. }\end{array}$ & $\begin{array}{l}\text { Continued } \\
\text { FMS/DCS efforts } \\
\text { can potentially } \\
\text { improve } \\
\text { economies of } \\
\text { scale and result in } \\
\text { further per unit } \\
\text { cost of the } \\
\text { Apache. FMS } \\
\text { sales can potential } \\
\text { offset cost of } \\
\text { future purchase of } \\
\text { upgraded Apaches } \\
\text { for the U.S. Army } \\
\text { fleet. }\end{array}$ & $\begin{array}{l}\text { Uncertainty of } \\
\text { Foreign Country } \\
\text { commitments, } \\
\text { coupled with U.S. } \\
\text { funds } \\
\text { programming lead } \\
\text { time creates cost } \\
\text { risk and/or quantity } \\
\text { of procurement } \\
\text { risk. }\end{array}$ \\
\hline $\begin{array}{l}\text { GCCS-J } \\
\text { Schedule }\end{array}$ & $\begin{array}{l}\text { Able to } \\
\text { abbreviate } \\
\text { delivery } \\
\text { schedules by } \\
\text { exploiting } \\
\text { initial } \\
\text { baseline(s) and } \\
\text { scaling from } \\
\text { there as } \\
\text { opposed to } \\
\text { developing } \\
\text { from the } \\
\text { ground up }\end{array}$ & $\begin{array}{l}\text { Multiple } \\
\text { schedules } \\
\text { increase multiple } \\
\text { opportunities to } \\
\text { miss }\end{array}$ & $\begin{array}{l}\text { Able to potentially } \\
\text { shorten future } \\
\text { delivery } \\
\text { timeframes by } \\
\text { developing fewer } \\
\text { baselines for } \\
\text { multiple } \\
\text { customers }\end{array}$ & $\begin{array}{l}\text { Delivery schedules } \\
\text { could be } \\
\text { jeopardized if } \\
\text { domestic and } \\
\text { international } \\
\text { requirements } \\
\text { compete with each } \\
\text { other for the same } \\
\text { resources }\end{array}$ \\
\hline $\begin{array}{l}\text { GCCS-M } \\
\text { Schedule }\end{array}$ & $\begin{array}{l}\text { Single } \\
\text { customer focus } \\
\text { limits schedule } \\
\text { permutations }\end{array}$ & $\begin{array}{l}\text { International } \\
\text { customer } \\
\text { pressure on } \\
\text { domestic release } \\
\text { schedules }\end{array}$ & $\begin{array}{l}\text { Domestic focus } \\
\text { should increase } \\
\text { probability of } \\
\text { being on time }\end{array}$ & $\begin{array}{l}\text { Challenges to } \\
\text { meeting the } \\
\text { demanding } \\
\text { domestic schedules } \\
\text { could cause } \\
\text { international } \\
\text { partners to look to } \\
\text { other C4ISR } \\
\text { products }\end{array}$ \\
\hline
\end{tabular}




\begin{tabular}{|c|c|c|c|c|}
\hline Program & Strengths & Weaknesses & Opportunities & Threats \\
\hline $\begin{array}{l}\text { F/A-18 } \\
\text { Schedule }\end{array}$ & $\begin{array}{l}\text { Able to } \\
\text { maintain } \\
\text { aggressive } \\
\text { delivery } \\
\text { schedules by } \\
\text { exploiting a } \\
\text { single baseline } \\
\text { design and } \\
\text { adding variants } \\
\text { on top }\end{array}$ & $\begin{array}{l}\text { Multiple } \\
\text { schedules } \\
\text { increase multiple } \\
\text { opportunities to } \\
\text { miss }\end{array}$ & $\begin{array}{l}\text { Potential ability to } \\
\text { align schedules of } \\
\text { both customer } \\
\text { bases }\end{array}$ & $\begin{array}{l}\text { Delivery schedules } \\
\text { could be } \\
\text { jeopardized if } \\
\text { domestic and } \\
\text { international } \\
\text { demands conflict } \\
\text { or compete }\end{array}$ \\
\hline $\begin{array}{l}\text { ATNAVICS } \\
\text { Schedule }\end{array}$ & None & $\begin{array}{l}\text { International } \\
\text { involvement } \\
\text { increases the } \\
\text { EMD schedule } \\
\text { significantly }\end{array}$ & $\begin{array}{l}\text { International } \\
\text { purchases could } \\
\text { provide } \\
\text { opportunities for } \\
\text { schedule } \\
\text { flexibility by } \\
\text { allowing to better } \\
\text { manage long term } \\
\text { production rates }\end{array}$ & $\begin{array}{l}\text { Significantly } \\
\text { increased schedule } \\
\text { would almost } \\
\text { certainly be a } \\
\text { result of } \\
\text { international } \\
\text { involvement }\end{array}$ \\
\hline $\begin{array}{l}\text { Apache } \\
\text { Schedule }\end{array}$ & $\begin{array}{l}\text { Provides } \\
\text { additional } \\
\text { stability to } \\
\text { production } \\
\text { schedule with } \\
\text { ability to } \\
\text { maintain } \\
\text { optimum } \\
\text { production } \\
\text { rate. }\end{array}$ & $\begin{array}{l}\text { Higher than } \\
\text { expected demand } \\
\text { by FMS and/or } \\
\text { DCS could place } \\
\text { U.S. Apache } \\
\text { schedule at risk } \\
\text { due to competing } \\
\text { demands on the } \\
\text { production line. }\end{array}$ & $\begin{array}{l}\text { International } \\
\text { purchases could } \\
\text { provide } \\
\text { opportunities for } \\
\text { schedule } \\
\text { flexibility and } \\
\text { allow better } \\
\text { managing of long } \\
\text { term production } \\
\text { rates. }\end{array}$ & $\begin{array}{l}\text { Potential for } \\
\text { international } \\
\text { cooperation/FMS/ } \\
\text { DCS adds } \\
\text { criticality to the } \\
\text { Apache Program } \\
\text { Protection Plan and } \\
\text { requires additional } \\
\text { scrutiny with } \\
\text { Information } \\
\text { Assurance } \\
\text { concerns. This } \\
\text { potentially puts } \\
\text { risk on the } \\
\text { schedule }\end{array}$ \\
\hline $\begin{array}{l}\text { GCCS-J } \\
\text { Performance }\end{array}$ & $\begin{array}{l}\text { Able to } \\
\text { accommodate } \\
\text { both domestic } \\
\text { and } \\
\text { international } \\
\text { C4ISR } \\
\text { requirements }\end{array}$ & $\begin{array}{l}\text { Limited } \\
\text { interoperability } \\
\text { testing } \\
\text { opportunities as a } \\
\text { result of } \\
\text { coordination } \\
\text { complexity }\end{array}$ & $\begin{array}{l}\text { Era of expanding } \\
\text { coalition } \\
\text { involvement and } \\
\text { increase U.S. } \\
\text { reliance on allies } \\
\text { provides more } \\
\text { opportunities to } \\
\text { meet and use } \\
\text { international } \\
\text { capability } \\
\text { requirements }\end{array}$ & $\begin{array}{l}\text { Information } \\
\text { assurance across a } \\
\text { broader spectrum } \\
\text { of customers could } \\
\text { open up system } \\
\text { vulnerabilities }\end{array}$ \\
\hline
\end{tabular}




\begin{tabular}{|c|c|c|c|c|}
\hline Program & Strengths & Weaknesses & Opportunities & Threats \\
\hline $\begin{array}{l}\text { GCCS-M } \\
\text { Performance }\end{array}$ & $\begin{array}{l}\text { Disclosure } \\
\text { Authority } \\
\text { responsible for } \\
\text { determining } \\
\text { final baseline } \\
\text { of capabilities } \\
\text { based on } \\
\text { releaseability }\end{array}$ & $\begin{array}{l}\text { Limited or no } \\
\text { influence on } \\
\text { system } \\
\text { integration } \\
\text { efforts for } \\
\text { international } \\
\text { customers on } \\
\text { their own system } \\
\text { baseline }\end{array}$ & $\begin{array}{l}\text { Limits complexity } \\
\text { in an already } \\
\text { complex } \\
\text { capabilities set }\end{array}$ & $\begin{array}{l}\text { Narrowly focusing } \\
\text { on a single } \\
\text { customer excludes } \\
\text { consideration of IA } \\
\text { postures/vulnerabil } \\
\text { ities and } \\
\text { information } \\
\text { sharing challenges } \\
\text { in the international } \\
\text { arena }\end{array}$ \\
\hline $\begin{array}{l}\text { F/A-18 } \\
\text { Performance }\end{array}$ & $\begin{array}{l}\text { Additional } \\
\text { resources from } \\
\text { international } \\
\text { sales allowed } \\
\text { multiple } \\
\text { variants whose } \\
\text { innovations } \\
\text { benefited all } \\
\text { customers }\end{array}$ & $\begin{array}{l}\text { Competing } \\
\text { domestic and } \\
\text { international } \\
\text { requirements } \\
\text { could result in } \\
\text { undesirable } \\
\text { tradeoffs for } \\
\text { stakeholders }\end{array}$ & $\begin{array}{l}\text { Increased } \\
\text { interoperability } \\
\text { and support } \\
\text { infrastructure with } \\
\text { allies }\end{array}$ & $\begin{array}{l}\text { Releaseability } \\
\text { and/or export } \\
\text { restrictions could } \\
\text { limit platform } \\
\text { capabilities and } \\
\text { potentially force } \\
\text { re-design if not } \\
\text { fully considered } \\
\text { before entering } \\
\text { into agreements }\end{array}$ \\
\hline $\begin{array}{l}\text { ATNAVICS } \\
\text { Performance }\end{array}$ & $\begin{array}{l}\text { None. It is } \\
\text { assumed that } \\
\text { there were no } \\
\text { existing TMR } \\
\text { technologies } \\
\text { available from } \\
\text { international } \\
\text { sources }\end{array}$ & $\begin{array}{l}\text { Holding with the } \\
\text { assumption that } \\
\text { no technology is } \\
\text { available from } \\
\text { international } \\
\text { sources, } \\
\text { performance } \\
\text { sacrifices would } \\
\text { need to be made } \\
\text { for the allowance } \\
\text { of international } \\
\text { participation }\end{array}$ & None & $\begin{array}{l}\text { Some, if not } \\
\text { significant, } \\
\text { reduction on } \\
\text { developed } \\
\text { performance would } \\
\text { be anticipated with } \\
\text { international } \\
\text { involvement. }\end{array}$ \\
\hline
\end{tabular}




\begin{tabular}{|c|c|c|c|c|}
\hline Program & Strengths & Weaknesses & Opportunities & Threats \\
\hline $\begin{array}{l}\text { Apache } \\
\text { Performance }\end{array}$ & $\begin{array}{l}\text { Additional } \\
\text { capabilities } \\
\text { developed and } \\
\text { tested through } \\
\text { the } \\
\text { Cooperative } \\
\text { Development } \\
\text { Agreement are } \\
\text { cost and risk } \\
\text { shared. This } \\
\text { allows for } \\
\text { potential } \\
\text { system } \\
\text { performance } \\
\text { improvement } \\
\text { that otherwise } \\
\text { may not be } \\
\text { affordable. The } \\
\text { additional } \\
\text { firepower and } \\
\text { war fighting } \\
\text { capability of } \\
\text { the Apache } \\
\text { being } \\
\text { distributed to } \\
\text { our Allies has } \\
\text { increased the } \\
\text { lethality of the } \\
\text { total Coalition. } \\
\text { Internationally } \\
\text { shared systems } \\
\text { and support } \\
\text { infrastructure } \\
\text { can result in an } \\
\text { overall reduced } \\
\text { life cycle } \\
\text { sustainment } \\
\text { cost for all } \\
\text { users. }\end{array}$ & $\begin{array}{l}\text { Added } \\
\text { complexity to an } \\
\text { already complex } \\
\text { platform }\end{array}$ & $\begin{array}{l}\text { Increase user base } \\
\text { can potential } \\
\text { reveal } \\
\text { opportunities for } \\
\text { performance } \\
\text { improvement. } \\
\text { Increase } \\
\text { international } \\
\text { partnerships open } \\
\text { opportunities for } \\
\text { foreign } \\
\text { technology that } \\
\text { otherwise may not } \\
\text { be available. }\end{array}$ & $\begin{array}{l}\text { Certain } \\
\text { technologies may } \\
\text { not get integrated } \\
\text { on or into the } \\
\text { Apache due to } \\
\text { concern about } \\
\text { exportability of the } \\
\text { overall system. } \\
\text { Some potential } \\
\text { performance } \\
\text { improvement } \\
\text { opportunities could } \\
\text { be sacrificed to } \\
\text { maintain } \\
\text { attractiveness to } \\
\text { the foreign market. }\end{array}$ \\
\hline
\end{tabular}




\section{Process for FMS/CP Engagement}

International consideration can be either a proactive or reactive task. If the capability that a PO is developing or producing is well established, then interested stakeholders can make availability inquiries through the normal channels. Those normal channels involve foreign partner requests through the COCOMs and/or Embassy Teams, to DSCA and service's international program office (IPO), such as NIPO or USASAC and then to the respective PO. If, however, the capability is not as well-known and the PO wants to reach out to see if there is international interest, then there are several avenues of engagement. The most direct way is to communicate directly with the COCOM that uses or will use the capability. The COCOMs and their service component commands work directly with the allied nations within their areas of responsibility and are one of the best sources for interoperability requirements. Official requests from the partner nations would go through the normal channels described above if any interest is gathered.

Another path is for the PO to approach their particular service's IPO such as NIPO or USASAC. The IPOs are the clearing house for incoming requests and know exactly what is being sold and to whom. They also have an understanding of capability gaps and trend analysis within the COCOMs and the service component commands within each COCOM. The IPOs can be used as a starting point for any level of international consideration from FMS to cooperative development.

Aside from actual engagement, coalition references within the National Security Strategy, National Defense Strategy and the National Military Strategies can give insight on international priorities. Such strategic alignments can influence the Joint Capabilities Integration Development System (JCIDS), the Planning, Programming, Budgeting and Execution process (PPBE) and ultimately the acquisition of defense capabilities. DSCA is also an avenue to determine what types of services and capabilities are being purchased and developed for/with international partners. Internally, program offices can look to their PEOs and Science and Technology communities for opportunities identified in technical gap analysis projects. This can be helpful in understanding where coalition gaps exist or where materializing international requirements may fill domestic gaps. 


\section{Entry Points in Defense Acquisition Cycle}

In contrast to what may be a typical international involvement philosophy of; "Let's build what we need and hope some foreign government will want to buy it" full consideration should include a spectrum of programs that start at the very earliest stages of the Acquisition process. Failure to involve particular international projects early may not preclude later involvement of other projects but, just like service unique domestic efforts, later additions of stakeholders and requirements almost always drive up cost and extend schedules at an increasing rate.

\section{a. Early Acquisition}

In the earliest stages of an acquisition effort, during the Materiel Solution Analysis phase, studies, exchanges of engineers and scientists and participation in the proper international forums will help harmonize requirements with potential international partners. These efforts may also lead to discovery of technology and resources available from international sources that would otherwise be overlooked. Gap analysis is the root of requirements development, but partial gap understanding will usually lead to incomplete requirements establishment. This sets the foundation for requirements creep later in the program.

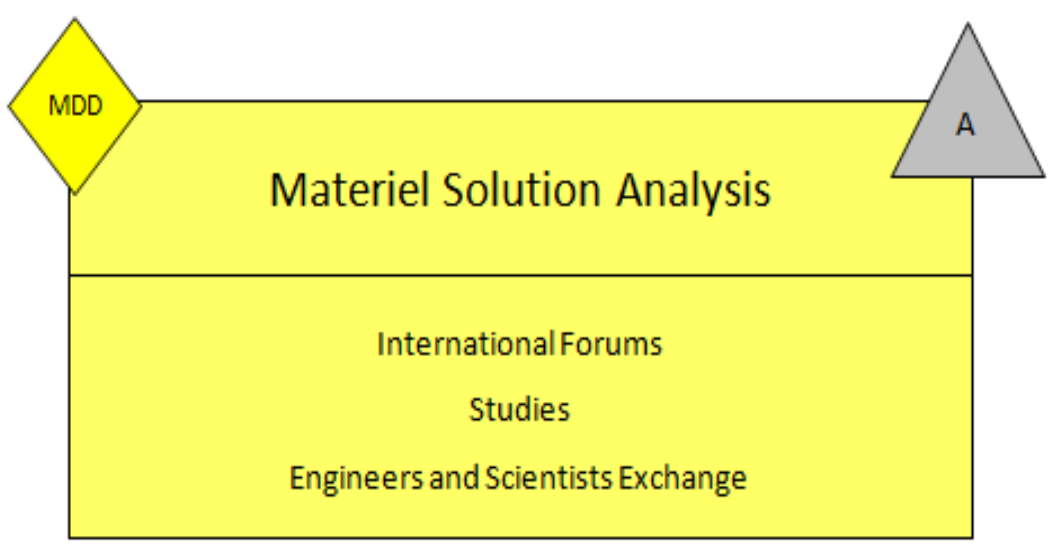

Figure 2. Materiel Solution Analysis 


\section{b. Middle Acquisition}

Two acquisition phases make up the majority of system development; Technology Maturation \& Risk Reduction, and Engineering \& Manufacturing Development. In addition to leveraging and maintaining the efforts established in the previous phase, a program office could consider; cooperative research, cooperative development, foreign cooperative testing, and no cost loans of equipment for RDT\&E.

System specific requirements are firmed up during the TM-RR phase with outputs being the Capabilities Development Document, the Technology Readiness Assessment, the Cost Estimates and all other Milestone B documentation. This phase is the ideal place to consider inclusion of international requirements, especially as they relate to Information Assurance, Critical Protected Information, and the ability to export the system.

Once the U.S. establishes valid User Requirement, the use of Foreign Comparative Testing opens the possibility to consider a foreign system to fulfill the gap. If a NDI foreign system is put through FCT and meets the requirements suitably and effectively, it would have priority over the development of a new system. This opportunity should be explored early in the acquisition process as it has the potential to shorten the entire process and save large amounts of development cost.

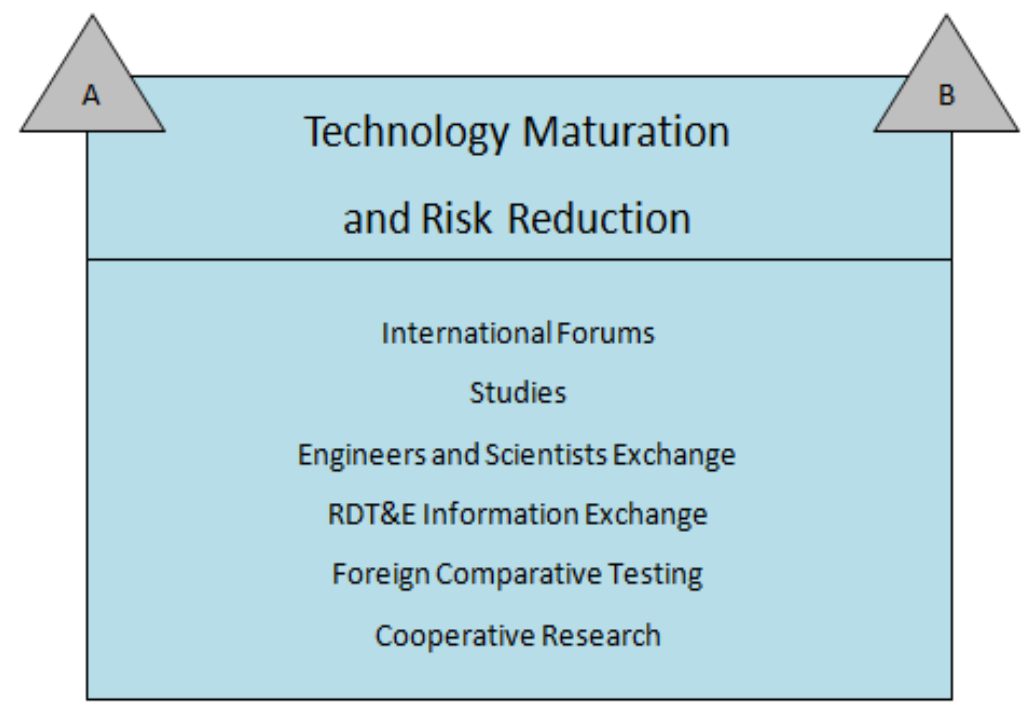

Figure 3. Technology Maturation and Risk Reduction 
As the system development progresses through the engineering \& manufacturing development (EMD) phase, the design is brought to near finalization and the manufacturing and integration of the subsystems and systems begins. Developmental testing and requirements validation occurs, which is the appropriate activity have integrated with established international partners. Schedules can be reduced and costs can be shared with the use of; cooperative development, foreign cooperative testing and the no cost loan of equipment for RDT\&E efforts. Full cooperative leveraging at this phase has the potential to reduce or eliminate costly changes later in the acquisition effort.

Once a decision has been made to develop a new system, FCT may still be a viable option when considering potential selection of NDI subsystems and/or components. At this point in the process full system FCT may not be an option but proportional savings of cost and schedule are still possible by using foreign items that meet the need.

International efforts from earlier phases of the program may still be appropriate, such as international forums, engineers and scientist exchanges and studies. Many programs delay some requirements to follow-on increments or post deployment upgrade efforts for one reason or another. Studies and other research type efforts during this phase will help later integration of those delayed capabilities.

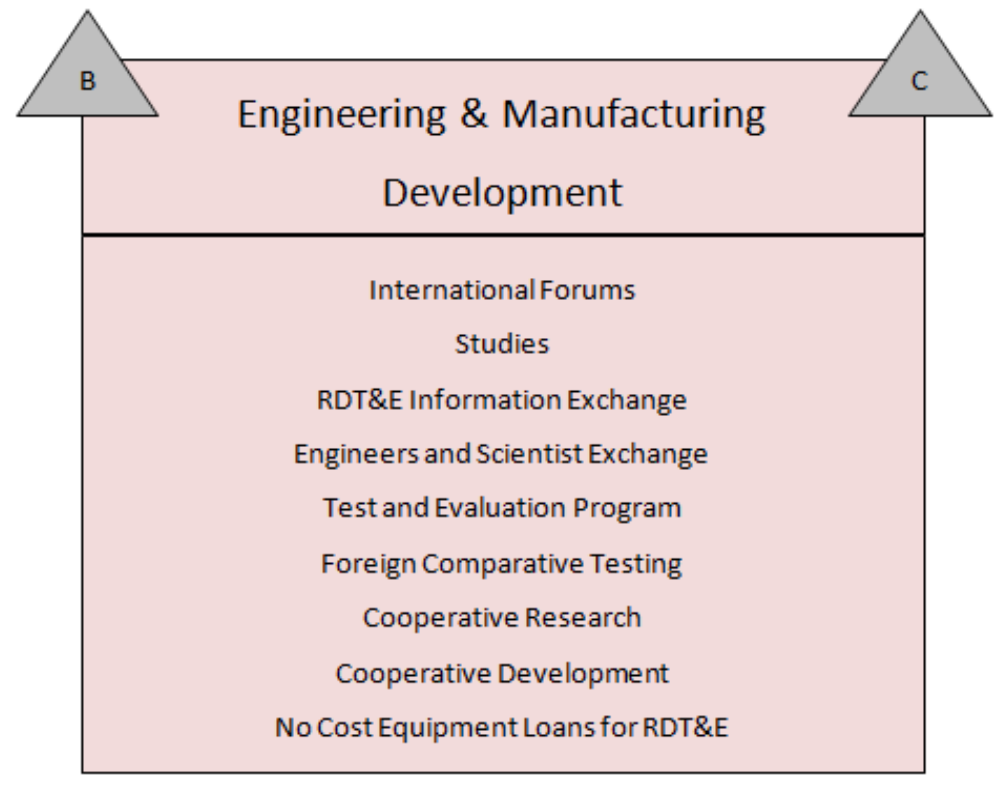

Figure 4. Engineering \& Manufacturing Development 


\section{c. Late Acquisition}

The final two phases of the Acquisition process begin with Milestone $\mathrm{C}$ and continue until the end of life (EOL) or disposal of the system. Initial Production and Operational Testing usually occur between the Milestone $\mathrm{C}$ decision and the full rate production (FRP) decision. Initial operational testing and evaluation (IOT\&E) is the critical capstone of the development and production effort where independent testing is done by actual operators. Failure at this point often means significant schedule slip to fix identified errors or even program cancellation. If international partners are involved at this point, it would be highly advantageous to share resources, data, facilities and evaluation effort related to the IOT\&E, which is the purpose of the foreign cooperative testing program. The use of no cost equipment loans for RDT\&E would also cover any foreign need to conduct independent $\mathrm{T} \& \mathrm{E}$ to satisfy unique foreign country requirements, threats, environments or support infrastructures.

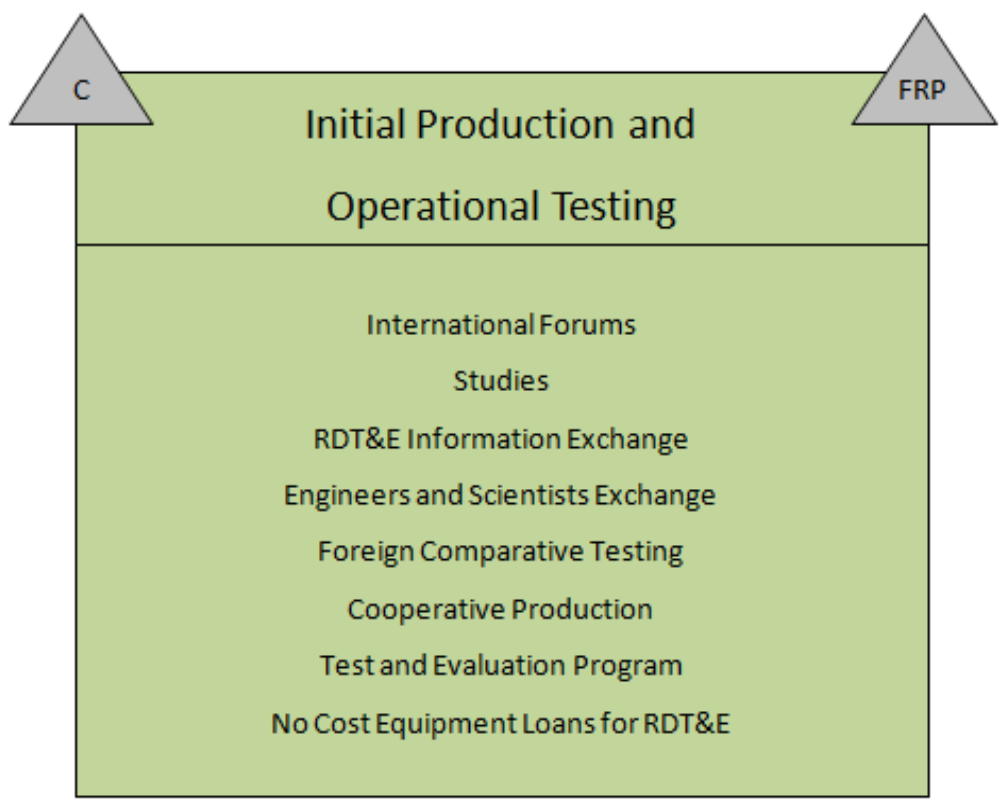

Figure 5. Initial Production and Operational Testing

It is worth noting that all of the phases leading up to this point are void of FMS and DCS. Program Managers involved with the early stages of acquisition considering the appropriate international involvement should ask their team "If we don't consider 
international cooperation now, can we afford to wait until after FRP to get an FMS case or let the contractor get DCS exports approved?" It is only during this final acquisition phase that FMC/DCS cases are approved without significant waivers from DOD and Congress. On the other hand, every international program conducted up to this point remains a valid consideration for continuation through this remaining phase. Some efforts are likely ramped down significantly, especially if this is the final or only increment of the development effort.

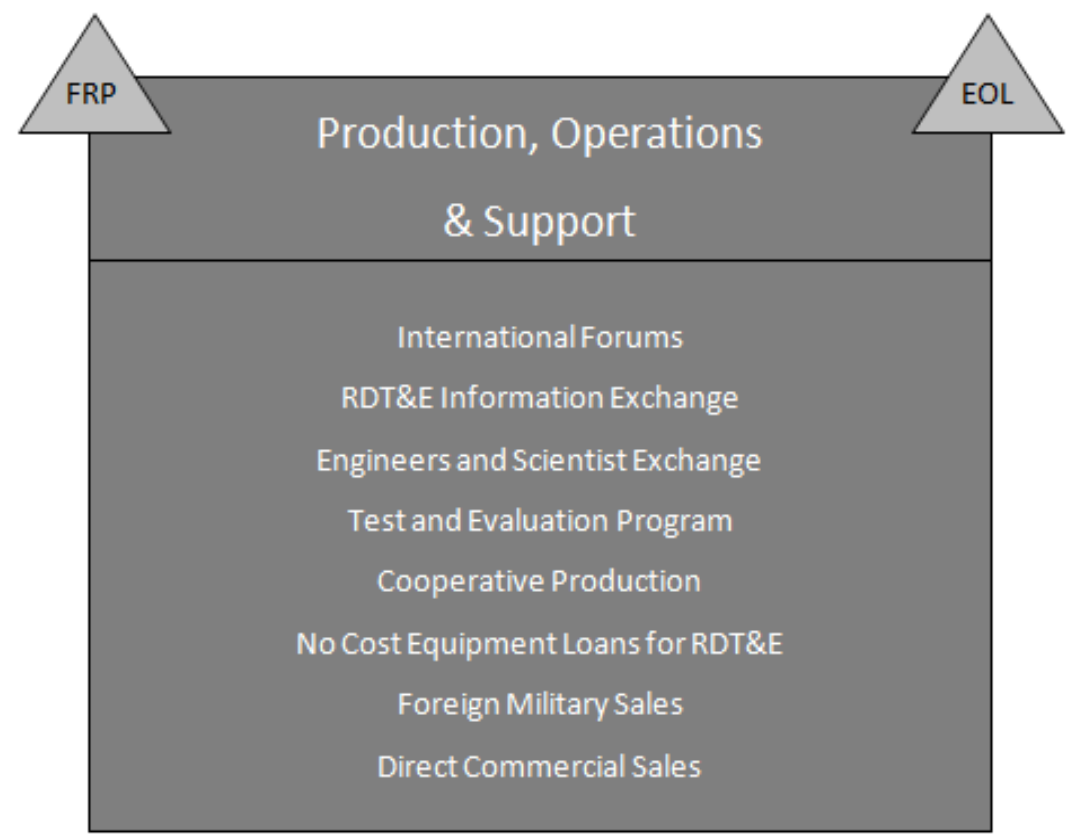

Figure 6. Production, Operations \& Support

\section{B. BARRIERS}

Several barriers exist to impede International involvement in the Acquisition Community, some real and some perceived. Part of the intent of this paper is to help clarify the understanding of the international cooperation efforts and as a result reduce many of the perceived barriers. The real barriers are not as simple to reduce, but take determined effort, early consideration and advanced planning to overcome. 


\section{Security}

A quote from the International Programs Security Handbook, chapter 8 "Systems Acquisition and Program Security Documents" puts security considerations in good perspective.

Past practice, the need for the best technologies available, and economic considerations suggest some involvement by allied and other friendly nations may occur in all but the most sensitive acquisition programs. Cooperation may be in the form of cooperative research \&development (R\&D), the use of foreign contractors and subcontractors, direct commercial sales (DCS), foreign military sales (FMS), or follow-on support. Realistically, there are very few defense articles the United States will not sell or share with an ally sometime during the life cycle of the article. Therefore, planning for some form of foreign participation must start early in the acquisition process. A key aspect of this planning involves decisions on access to classified information and critical unclassified technical data and the protection of system capabilities and vulnerabilities, which are based on the underlying technology. ${ }^{21}$

Dealing with the challenges of IA, including control of critical protection information (CPI), classified information and critical unclassified technical data can be a daunting task for the PM staff to tackle in a domestic program. Add the complexity of international involvement and it becomes an obvious barrier. The best way to break down this barrier is to incorporate the direct support of knowledgeable International Program and/or FMS experts on the integrated process/product team (IPT). As a second alternative, identify competent existing members of the IPT who can attend training to become knowledgeable advisors. Guidance is abundant and a good place to start is the International Programs Security Handbook. To re-emphasize the quote, the key is to start early in the acquisition process. Doing this has the potential to eliminate latent symptomatic "barriers" such as these examples:

- $\quad$ Attempting to integrate U.S. systems with a foreign government managed network with incompatible security, or security measure that were not properly verified, tested or monitored.

21 Under Secretary of Defense Technology Security Policy \& National Disclosure Policy. International Programs Security Handbook, Washington, DC: Under Secretary of Defense, 2010. 
- $\quad$ Selecting components or subsystems that have unnecessarily high security classifications for the application which results in excessive limitations on international cooperation, FMS or DCS.

- Upgrades developed that "break" international interoperability or exportability.

\section{Expectation Challenges}

Cultural differences may also cause friction or misunderstandings. The U.S. DOD Acquisition systems is complex, slow to respond, and in all but the most urgently needed efforts, anything but agile. This can be very frustrating, not only from the inside looking out, but from the outside looking in. U.S. Program Managers may have international opportunities that present themselves but never materialize simply due to the bureaucratic challenges. This combined with language and cultural barriers can lead to differing expectations if not carefully coordinated amongst all stakeholders.

\section{Implied/Actual Added Cost in Future International Engagements}

Cost stability and quantity purchase discounts are sought after benefits of Joint and International participation. These can sometimes be illusive in execution due to shifting budget priorities of both countries, escalating costs during development and early production, or poor cost estimating that all drive participating countries to either back out of participation or reduce the desired quantities. This causes second order impacts of further cost increases of the remaining quantities purchased by the U.S. It does not take many instances like this to make a PM think twice before entering into an International Agreement.

\section{U.S. Priorities}

The tendency of most PMs is to not only put the U.S. priorities at the top of the list, but also put their own service priorities up there too. The culture and reward structure of the DOD supports the continuation of this trend. 


\section{CURRENT ATMOSPHERE}

The atmosphere for international consideration is currently very active and involves the U.S. DOD but also U.S. industry and the international defense community. Under severe national financial pressure, the U.S. DOD is experiencing declining budgets and significant reductions in military involvement in both the Iraq and Afghanistan campaigns. As a result of this, program offices are faced with funding cuts, increased scrutiny over justification and even program cancelations. International involvement can offer additional opportunities to help offset some of these negative impacts if it can be aligned with what remains of the domestic cost, schedule and performance objectives. On the negative side of the consideration though, if a program has to stop mid-effort to consider international cooperation or FMS, the additional delay, cost or performance changes may be enough to drop the program below the "Cut Line" of the priorities list.

The recent increase in USG participation at the 2014 Farnborough Air Show has indicated a renewed interest in supporting the U.S. Industrial base in this forum as well as meeting with other international partners and gaining exposure to new technologies as Aaron Mehta noted in the Defense News article on July 19, 2014. U.S. DOD Industries also realize this and are leading the charge in international engagement opportunities. Their future may depend on them diversifying into the international defense arena to help offset the declines in the U.S. DOD budgets. As stated by the Chief Executive Officer of the U.S. Aerospace Industries Association, Marion Blakey during an interview with Aaron Mehta at the Farnborough Air Show: "International sales normally form the backbone of interoperability with our friends and allies, as well as helping to keep pricing and costs down and manufacturing lines open. In a constrained domestic budget environment, our member companies increasingly are turning to the international market."

The recent Better Buying Power (BBP) 2.0 has also placed emphasis on including defense exportability features early in the design process. Under the focus area "Control Costs Throughout the Product Life cycle," this initiative is one of 36 under seven focus areas to "ensure affordability and increase productivity in defense spending to deliver 
better value to the taxpayer and Warfighter". ${ }^{22}$ Benefits highlighted in this initiative include reduced cost, improved U.S. competitiveness, stronger ties to friends and allies, and improved interoperability. ${ }^{23}$

With reductions in the U.S. DOD budget and reductions in military involvement, the international defense community is also seeking ways to continue to build their own capability. Either directly with industry in DCS with the U.S. or other nations in FMS, they have a strong demand for services and rapidly delivered capabilities. Both the USG and the U.S. DOD industrial base stand a good chance of capitalizing on this increased demand if the international resources exist and if alignment can be accomplished between all three.

22 F. Kendall, Better Buying Power 2.0: Continuing the Pursuit for Greater Efficiency and Productivity in Defense Spending [Memorandum]. (Washington, DC: Office of the Under Secretary of Defense (AT\&L), November 13, 2012).

23 F. Kendall, Better Buying Power 2.0: Continuing the Pursuit for Greater Efficiency and Productivity in Defense Spending [Memorandum]. (Washington, DC: Office of the Under Secretary of Defense (AT\&L), November 13, 2012). 


\section{SUMMARY AND RECOMMENDATIONS}

\section{A. SUMMARY}

In Chapter I, several questions were posed in an attempt to investigate if the utilization of U.S. interoperability requirements of our foreign allies could enhance expand and potentially reduce the cost of our domestically acquired capabilities. To answer these questions a high level overview of International Armament Cooperation was presented to explain the foundation and the tie-ins to the DAS. From there, a stakeholder analysis was presented to form the basis of expectations when working within IAC and its overlap with the DAS. Finally, several program examples were provided and analyzed to show examples of early, middle, late or no international consideration.

The first question dealt directly with determining if early and continuous consideration of foreign interoperability requirements within domestic DOD acquisitions can benefit the United States Armed Forces acquisitions in terms of cost, schedule and performance. Here, alignment and performance are the keys to success. Cost and Schedule known and unknowns will almost certainly increase, however if they can be aligned with both the domestic and international expectations as much as possible the overall burden and risk to the PO may be reduced. From the performance perspective, interoperability, increased coalition performance, and increased industrial base are the consistent pay-outs of international participation.

The second question posed placed emphasis on how a domestic Program Office would determine if foreign interoperability requirements exist for their product(s) and/or service(s). Early stakeholder engagement and participation in international forums, exchanges of engineers and scientists, and use of the information exchange programs early in the acquisition process are keys to success in this area. These opportunities should be done preferably during the Solution Analysis phase, but at least during the TMRR phase. 
Finally, the third question required an exploration of process to help a PM determine how to implement foreign interoperability requirements into their product(s) and/or service(s). To accomplish this, a description of the full spectrum of IAC/FMS/DCS, the appropriate entry points, barriers and rewards was provided. The intent of this description was to help establish that direct involvement of International Program/FMS/DCS SME's in the IPT early and continuously is possible throughout the Acquisition process.

\section{B. RECOMMENDATIONS}

\section{Increase the DOD International Program and Foreign Military Sales Staffing}

Program Managers and IPTs need access to staff that is skilled in IP, IC, FMS and DCS at every stage of the acquisition life cycle. Early and thorough analysis of the benefits and costs of using the appropriate mix of security cooperation is critical to enable the opportunities at later stages. Poorly informed decisions early can result in derailing attempts to integrate an international effort in subsequent phases. The current DOD staffing appears to be biased toward FMS and DCS and maybe insufficient to support the remainder of the possibilities except in only the largest ACAT-I programs.

There are at least two methods to accomplish this recommendation. First, dedicated staff could be increased for IP support that would allow for more matrixed type support of the PM and IPTs. Second, current staff from other competencies could assume additional responsibilities of becoming more knowledgeable in the cooperative program efforts. The proficiency could be enhanced through temporary rotational assignments after appropriate coursework. The ultimate end result should be a much larger workforce competent in international efforts and available to support the acquisition process at all stages.

\section{In-depth Analysis of the Joint Strike Fighter Program}

Recommend future research on the Joint Strike Fighter program as an example of a cooperative development program in its Initial Production and Operational Testing phase. 
The Joint Strike Fighter program is a very complex program with numerous countries involved in the design and manufacturing processes and a very large population of stakeholders that span the spectrum from operational users in every service through elected officials that represent over 30 States. As the program makes it way to Production, Operations \& Support, there may be many lessons learned regarding the program's effects, both positive and negative, on cost sharing, economies of scale and quicker implementation times.

\section{CONCLUSION}

While only touching the surface on DOD acquisition program examples and limiting the research to what was publically available a conclusion can be drawn that when domestic and international cost, schedule and performance requirements align, opportunities to leverage can exist. Barriers, however, must be considered since they could ultimately increase risk and cause misalignment. Ultimately it is in our National interest for U.S. DOD Program Offices and their PM's to consider our international partnerships to help enhance, expand and potentially reduce the cost of our domestically acquired capabilities. This is in conjunction with the opportunity to better equip our allies and render them more effective coalition partners and assist with establishing stronger international relations. 
THIS PAGE INTENTIONALLY LEFT BLANK 


\section{APPENDIX}

The following tables are consolidated listings of SA programs and SC programs. The governing documents that apply to each program are listed in Table 3 for the SA programs. None are listed in Table 4, as all SC programs are authorized by the National Defense Authorizations and Appropriations Acts and are all managed by DOD.

Table 3. Security Assistance Programs 24

\begin{tabular}{|c|c|c|c|}
\hline Program & Oversight & Purpose & Governing Document \\
\hline Foreign Military Sales & DSCA & $\begin{array}{l}\text { Eligible foreign governments } \\
\text { purchase U.S. Defense articles, } \\
\text { services and training. }\end{array}$ & $\begin{array}{l}\text { AECA Section 21: Items } \\
\text { from existing stock } \\
\text { AECA Section 22: Items } \\
\text { from new procurement }\end{array}$ \\
\hline $\begin{array}{l}\text { Foreign Military } \\
\text { Construction Services }\end{array}$ & DSCA & $\begin{array}{l}\text { Sale of design and construction } \\
\text { service to eligible purchasers }\end{array}$ & AECA Section 29 \\
\hline $\begin{array}{l}\text { Foreign Military } \\
\text { Financing Program }\end{array}$ & DSCA & $\begin{array}{l}\text { Provides grants and loans which } \\
\text { enable eligible foreign } \\
\text { governments to purchase U.S. } \\
\text { defense articles, services, and } \\
\text { training. }\end{array}$ & AECA Section $23 \& 24$ \\
\hline Leases & DSCA & $\begin{array}{l}\text { Allows the lease of defense } \\
\text { articles only for compelling } \\
\text { foreign policy or national security } \\
\text { reasons. }\end{array}$ & AECA Chapter 6 AECA \\
\hline $\begin{array}{l}\text { Military Assistance } \\
\text { Program }\end{array}$ & DSCA & $\begin{array}{l}\text { Merged with the FMFP program } \\
\text { in } 1990 \text {. Remains an open } \\
\text { program only to track open } \\
\text { activities from pre-1990. }\end{array}$ & \\
\hline $\begin{array}{l}\text { International Military } \\
\text { Education and } \\
\text { Training }\end{array}$ & DSCA & $\begin{array}{l}\text { Provides grant financial } \\
\text { assistance of training in the U.S. } \\
\text { and, in some cases, overseas } \\
\text { facilities to selected foreign } \\
\text { military and civilian personnel. }\end{array}$ & $\begin{array}{l}\text { FAA Section } 541 \\
\text { FAA section } 644(\mathrm{~m})(5) \\
\text { AECA Section } \\
21(\mathrm{a})(1)(\mathrm{C})\end{array}$ \\
\hline Expanded IMET & DSCA & $\begin{array}{l}\text { Focuses training on developing } \\
\text { professional level management } \\
\text { skills with emphasis on military } \\
\text { justice systems, codes of conduct, } \\
\text { and the protection of human } \\
\text { rights. }\end{array}$ & $\begin{array}{l}\text { FAA Section } 541 \\
\text { FAA section } 644(\mathrm{~m})(5) \\
\text { AECA Section } \\
21(\mathrm{a})(1)(\mathrm{C})\end{array}$ \\
\hline
\end{tabular}

24 Derived from Defense Institute of Security Assistance Management, The Management of Security Cooperation (Green Book), $33^{\text {rd }}$ ed. (Write-Patterson Air Force Base, Ohio, Defense Institute of Security Assistance Management, 2014), (1-1-1-6). 


\begin{tabular}{|c|c|c|c|}
\hline Program & Oversight & Purpose & Governing Document \\
\hline Drawdowns & DSCA & $\begin{array}{l}\text { Provide USG articles, services } \\
\text { and training to friendly countries } \\
\text { and international organizations at } \\
\text { no cost during a crisis }\end{array}$ & $\begin{array}{l}\text { FAA section } 506 \\
\text { FAA section } 552 @(2)\end{array}$ \\
\hline $\begin{array}{l}\text { Economic Support } \\
\text { Fund }\end{array}$ & USAID & $\begin{array}{l}\text { Promote economic and political } \\
\text { stability in areas where the U.S. } \\
\text { has special political and security } \\
\text { interest and where the U.S. has } \\
\text { determined that economic } \\
\text { assistance can be useful in } \\
\text { helping to secure peace or to avert } \\
\text { major economic or political } \\
\text { crises. }\end{array}$ & FAA Chapter 4 of part II \\
\hline $\begin{array}{l}\text { Peacekeeping } \\
\text { Operations }\end{array}$ & DOS & $\begin{array}{l}\text { Provides funds for Multinational } \\
\text { Force and Observers and support } \\
\text { of peacekeeping efforts where } \\
\text { necessary. }\end{array}$ & FAA Chapter 6 of part II \\
\hline $\begin{array}{l}\text { Global Peace } \\
\text { Operations Initiative } \\
\text { (GPOI) }\end{array}$ & $\begin{array}{l}\text { DOS with } \\
\text { DOD } \\
\text { support }\end{array}$ & $\begin{array}{l}\text { The current principal } \\
\text { Peacekeeping Operations } \\
\text { program. Supports deployment of } \\
\text { peacekeepers by providing } \\
\text { equipment, transportation, } \\
\text { training, and sustainment in the } \\
\text { field. }\end{array}$ & \\
\hline $\begin{array}{l}\text { International narcotics } \\
\text { Control and Law } \\
\text { Enforcement (INCLE) }\end{array}$ & DOS & $\begin{array}{l}\text { Suppress the worldwide illicit } \\
\text { manufacture and trafficking of } \\
\text { narcotic and psychotropic drugs, } \\
\text { money laundering, and precursor } \\
\text { chemical diversion and the } \\
\text { progressive elimination of the } \\
\text { illicit cultivation of the applicable } \\
\text { crops. }\end{array}$ & FAA section 481 \\
\hline $\begin{array}{l}\text { Nonproliferation, } \\
\text { Antiterrorism, } \\
\text { Demining, and } \\
\text { Related Programs }\end{array}$ & DOS & $\begin{array}{l}\text { Supports demining activities, the } \\
\text { clearance of unexploded } \\
\text { ordnance, the destruction of small } \\
\text { arms, border security, and related } \\
\text { activities. Related articles, } \\
\text { services and training can also be } \\
\text { provided. }\end{array}$ & $\begin{array}{l}\text { FAA part II, chapters } 8 \& \\
9 \\
\text { AECA Section } 23 \\
\text { FREEDOM Support Act } \\
\text { section } 504\end{array}$ \\
\hline $\begin{array}{l}\text { Direct Commercial } \\
\text { Sales }\end{array}$ & $\begin{array}{l}\text { DOS; } \\
\text { (PM/DDT } \\
\text { C) }\end{array}$ & $\begin{array}{l}\text { Commercial exports of defense } \\
\text { articles, services and training. }\end{array}$ & $\begin{array}{l}\text { AECA section } 38 \\
\text { ITAR [22 CFR 120-130] }\end{array}$ \\
\hline $\begin{array}{l}\text { Excess Defense } \\
\text { Articles }\end{array}$ & DOD & $\begin{array}{l}\text { Excess defense articles are } \\
\text { authorized for sale using the FMS } \\
\text { processes. }\end{array}$ & $\begin{array}{l}\text { AECA section } 21 \\
\text { FAA section } 516\end{array}$ \\
\hline $\begin{array}{l}\text { Third Country } \\
\text { Transfers }\end{array}$ & DOS & $\begin{array}{l}\text { Transfer U.S.-origin defense } \\
\text { articles from the original recipient } \\
\text { country to a third country. }\end{array}$ & AECA section 3(d) \\
\hline
\end{tabular}


Table 4. Security Cooperation Programs 25

\begin{tabular}{|l|l|}
\hline Program & Purpose \\
\hline Security Assistance & $\begin{array}{l}\text { Foreign Military Sales, Foreign Military Construction Services, } \\
\text { Foreign Military Financing Program, Leases, Military Assistance } \\
\text { Program, International Military Education and Training, } \\
\text { Drawdowns, Excess Defense Articles when administered by DOD. }\end{array}$ \\
\hline Global Train and Equip & $\begin{array}{l}\text { Currently about 18 programs that Train and/or Equip Foreign } \\
\text { Security and/or Military Forces. }\end{array}$ \\
\hline $\begin{array}{l}\text { International Armaments } \\
\text { Cooperation }\end{array}$ & $\begin{array}{l}\text { Also known as simply International Cooperation. Includes: } \\
\text { Information Exchange Program, Exchange of Engineers \& } \\
\text { Scientists, Foreign Comparative Testing, Cooperative RDT\&E and } \\
\text { Production, No-Cost Equipment Loans, Cooperative Threat } \\
\text { Reduction Program, Israeli Cooperative Programs, International Air } \\
\text { and Trade Shows, Humanitarian Assistance, }\end{array}$ \\
\hline Humanitarian Assistance & $\begin{array}{l}\text { Humanitarian and Civic Action during Military Operations, } \\
\text { Humanitarian Assistance Transportation, Foreign Disaster Relief, } \\
\text { Humanitarian Daily Rations, Excess Property Humanitarian } \\
\text { Assistance, Humanitarian Demining Assistance, Commander's } \\
\text { Emergency Response Program, Reintegration Activities in } \\
\text { Afghanistan, Afghanistan Infrastructure Fund }\end{array}$ \\
\hline $\begin{array}{l}\text { Megional Defense Combating Terrorism Fellowship Program, DOD } \\
\text { Contacts }\end{array}$ & $\begin{array}{l}\text { Regional Centers for Security Studies, Military Academies, Military } \\
\text { Academy Student Exchanges, U.S. Coast Guard Academy, } \\
\text { Electronic Distribution of Training Material, Aviation Leadership } \\
\text { program, Latin America Training Waiver, Distinguished Visitor } \\
\text { Orientation Tours, Professional Military Education Student } \\
\text { Exchanges, Flight Student Exchanges, Flight Leadership Training in } \\
\text { Southwest Asia, unit Exchanged training, Air Force partnership for } \\
\text { Peace Scholarship }\end{array}$ \\
\hline $\begin{array}{l}\text { Exercises between the forces of the U.S. and those of one or more } \\
\text { other countries. The primary purpose is the training of the U.S. } \\
\text { forces, emphasizing interoperability and capability building. }\end{array}$ \\
$\begin{array}{l}\text { M2M contacts and comparable activities that are designed to } \\
\text { encourage a democratic orientation of defense establishments and } \\
\text { military forces of other countries. }\end{array}$ \\
\hline
\end{tabular}

25 Derived from Defense Institute of Security Assistance Management, The Management of Security Cooperation (Green Book), $33^{\text {rd }}$ ed. (Write-Patterson Air Force Base, Ohio, Defense Institute of Security Assistance Management, 2014), (1-7-1-26). 
THIS PAGE INTENTIONALLY LEFT BLANK 


\section{LIST OF REFERENCES}

“International Cooperation in DOD Acquisition." Last modified September 5, 2014. http://acq.osd.mil/ic/Intl\%20Coop\%20in\%DOD\%20ACQ.html.

Defense Acquisition University. Defense Acquisition Guidebook (DAG). Online Version, https://dag.dau.mil/Pages/Default.aspx, September 2014.

Defense Information Systems Agency. “GCCS-Joint.” Accessed September 15, 2014.

Defense Institute of Security Cooperation. The Management of Security Cooperation (Green Book). 33 ${ }^{\text {rd }}$ ed. Write-Patterson Air Force Base, OH: Defense Institute of Security Assistance Management, 2014.

Defense Security Cooperation Agency. Electronic-Security Assistance Management Manual. DODD 5105.38M. Arlington VA: Defense Security Cooperation Agency, 2012.

FedBizOps.gov. "GCCS-J Program Control Acquisition Management Support Services." Last modified October 21, 2009.

Kendall, F. Better Buying Power 2.0: Continuing the Pursuit for Greater Efficiency and Productivity in Defense Spending. [Memorandum]. Washington, DC: Office of the Under Secretary of Defense (AT\&L), November 13, 2012.

NAVAIR.navy.mil. "F/A-18 FMS Manager's Efforts Result in \$1 Billion in Savings." Last modified April 30, 2013.

Public.navy.mil. "Global Command and Control System-Maritime (GCCS-M)." Accessed on September 15, 2014.

Under Secretary of Defense (AT\&L). International Cooperation in Acquisition, Technology and Logistics (IC in AT\&L) Handbook. $7^{\text {th }}$ ed. Washington DC: Under Secretary of Defense (AT\&L), 2012.

Under Secretary of Defense (AT\&L). The Defense Acquisition System. DOD Directive 5000.1. Washington, DC: Under Secretary of Defense (AT\&L), 2007.

Under Secretary of Defense Technology. Security Policy \& National Disclosure Policy. International Programs Security Handbook. Washington, DC: Under Secretary of Defense, 2010. 
THIS PAGE INTENTIONALLY LEFT BLANK 


\section{INITIAL DISTRIBUTION LIST}

1. Defense Technical Information Center FT Belvoir, Virginia

2. Dudley Knox Library Naval Postgraduate School

Monterey, California 